OECDpublishing

GVC CENTRALITY AND PRODUCTIVITY: ARE HUBS KEY TO FIRM PERFORMANCE? CHIARA CRISCUOLO JONATHAN TIMMIS

\title{
OECD PRODUCTIVITY
} WORKING PAPERS June 2018 No. 14 


\section{OECD PRODUCTIVITY WORKING PAPERS}

The OECD Productivity Working Papers are associated with the Global Forum on Productivity that provides a forum for mutual exchange of information and fosters international co-operation between public bodies with responsibility for promoting productivity-enhancing policies, including in undertaking joint policy analysis. It offers a platform for exchanging views, experiences and information, institutional and governance arrangements and government structures, with a view towards developing better policies. The Forum extends existing work in the OECD through a well-prioritised and coherent stream of analytical work serving the policy research needs of participants on the drivers of productivity growth.

This paper has been authorised for publication by Luiz de Mello, Director, Policy Studies Branch.

OECD Productivity Working Papers should not be reported as representing the official views of the OECD or of its member countries. The opinions expressed and arguments employed are those of the author(s).

Comments on OECD Productivity Working Papers are welcome and may be sent to: productivity@oecd.org

OECD Productivity Working Papers are published on: oe.cd/productivity

Series: OECD Productivity Working Paper Series

ISSN 2413-9424

Please cite this paper as:

Criscuolo, C., and Timmis J., "GVC centrality and productivity: Are hubs key to firm performance?", OECD Productivity Working Papers, 2018-14, OECD Publishing, Paris.

This document and any map included herein are without prejudice to the status of or sovereignty over any territory, to the delimitation of international frontiers and boundaries and to the name of any territory, city or area.

(C) OECD (2018)

You can copy, download or print OECD content for your own use, and you can include excerpts from OECD publications, databases and multimedia products in your own documents, presentations, blogs, websites and teaching materials, provided that suitable acknowledgment of OECD as source and copyright owner is given. All requests for commercial use and translation rights should be submitted to rights@oecd.org 


\title{
ABSTRACT/RÉSUMÉ
}

\author{
GVC centrality and productivity: Are hubs key to firm performance?
}

This paper uses "centrality" metrics to reflect the changing structure of Global Value Chains (GVCs), contrasting central hubs and peripheral countries and sectors, and examine how these changes impact firm productivity. Using cross-country firm-level data from ORBIS, the paper finds that changing position within GVCs can play a role in the catch up of firms, but the results are heterogeneous across firms and countries. Firstly, becoming more central is associated with faster productivity growth of smaller firms, nonfrontier businesses, and of firms in smaller economies and in post-2004 EU member countries. And these correlations weaken with firm size and with proximity to the frontier, such that when one ignores firm heterogeneity and only considers average effects, there is no correlation for the average firms in the data. Secondly, the (centrality weighted) average productivity of buyers matters for the productivity of firms in our data overall, however this is particularly true for firms in large economies, for non-frontier and for smaller firms. The policy environment, such as flexible labour markets, better access to finance, stronger contract enforcement and simplified export procedures, appears to be important in translating the changing structure of GVCs into faster productivity growth of these non-frontier firms.

JEL classification: F12, F14, D22, L25

Keywords: Productivity, firms, global value chains, centrality, network analysis

\section{Centralité et productivité dans les chaînes de valeur mondiales : les pôles centraux sont-ils essentiels aux performances des entreprises ?}

Ce document fait appel à un indicateur de « centralité » pour rendre compte des évolutions dans la structure des chaînes de valeur mondiales (CVM), pointant les différences entre pôles centraux, pays périphériques et secteurs, et pour examiner comment ces évolutions ont des effets sur la productivité des entreprises. À partir des données internationales recueillies auprès des entreprises de la base de données ORBIS, on observe que les changements de position dans les CVM peuvent jouer un rôle dans la capacité des entreprises à rattraper leur retard, mais les résultats sont toutefois hétérogènes entre les entreprises et les pays. Premièrement, le fait d'occuper une position plus centrale va de pair avec une croissance plus rapide de la productivité des plus petites entreprises, de celles qui sont à distance de la frontière, des entreprises résidentes d'économies de taille plus modeste et des pays devenus membres de l'UE à la suite de l'élargissement de 2004. On observe également que ces corrélations s'affaiblissent avec la taille des entreprises et avec leur proximité par rapport à la frontière, à telle enseigne que si l'on fait abstraction de leur hétérogénéité et que l'on ne considère que les effets moyens, les données ne présentent plus aucune corrélation pour les entreprises moyennes. Deuxièmement, nos données nous permettent d'établir que la productivité moyenne des acheteurs (pondérée en fonction de la centralité de leur position) est un facteur qui compte, globalement, pour la productivité des entreprises, mais qu'il en va particulièrement ainsi pour les entreprises résidentes des grandes économies et pour celles qui sont à distance de la frontière ou de taille plus petite. Les politiques publiques menées, notamment la flexibilité du marché du travail, la facilité d'accès au financement, la rigueur des règles d'exécution des contrats et la simplification des procédures d'exportation se révèlent être des facteurs importants pour que les changements de position dans les CVM se traduisent par des gains de productivité plus rapides pour ces entreprises à distance de la frontière.

Mots-clés: productivité, entreprises, chaînes de valeur mondiales, centralité, analyse de réseau.

Codes de classification JEL: F12, F14, D22, L25 


\section{Table of contents}

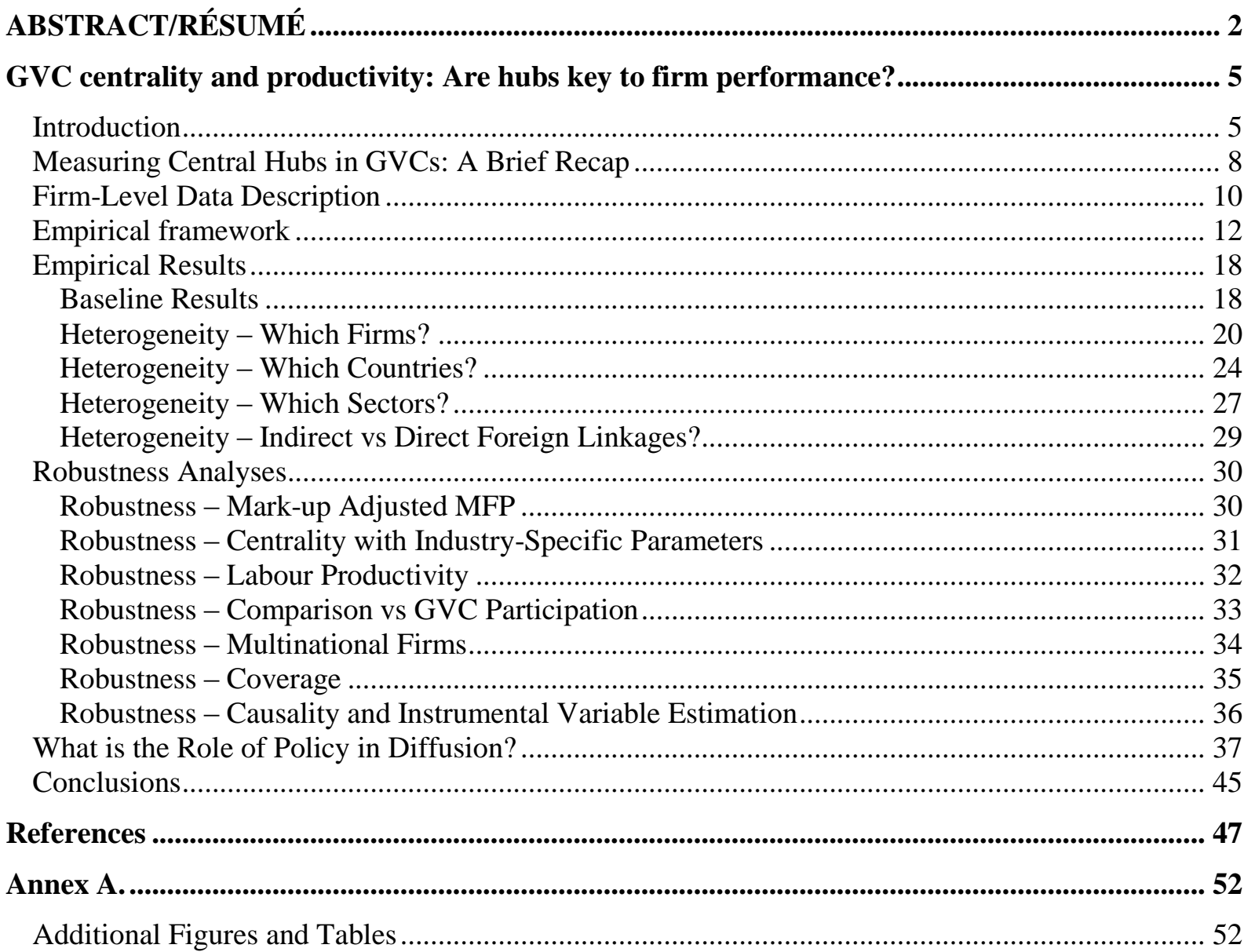

\section{Tables}

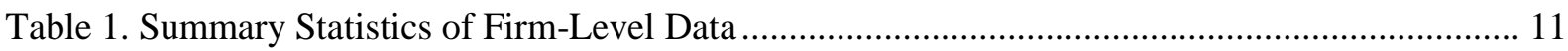

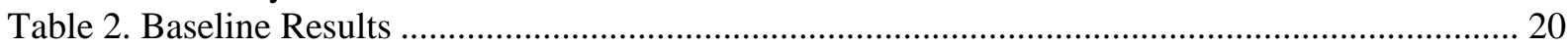

Table 3. Heterogeneity by firm type: Frontier vs Non-frontier and Large vs Small ............................ 23

Table 4. Heterogeneity by country: Post-2004 EU Accession vs Other Factory Europe ....................... 27

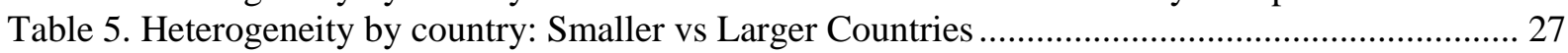

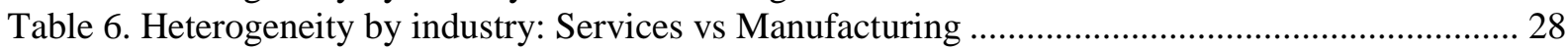

Table 7. Heterogeneity by Direct or Indirect Foreign Linkages............................................................. 30

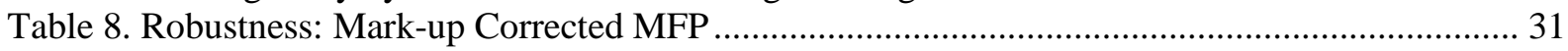

Table 9. Robustness: Centrality with Industry-Specific Parameters ................................................. 32

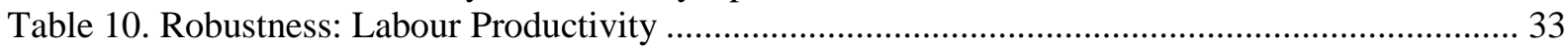




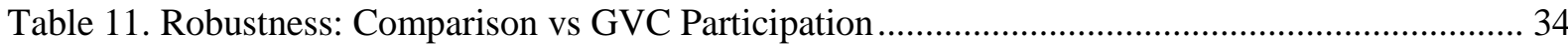

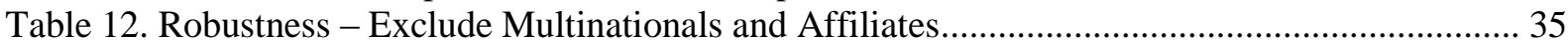

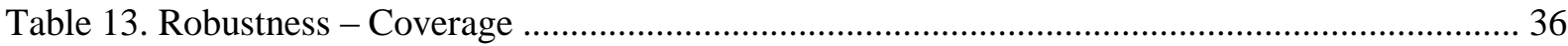

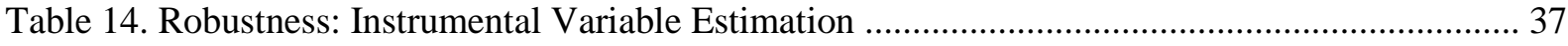

Table 15. What is the Role of Policy in Diffusion? Labour and Product Market Flexibility ................ 41

Table 16. What is the Role of Policy in Diffusion? Trade and Investment Barriers .............................. 43

Table 17. What is the Role of Policy in Diffusion? Contract Enforcement ......................................... 44

Table 18. What is the Role of Policy in Diffusion? Barriers to Entrepreneurship and Access

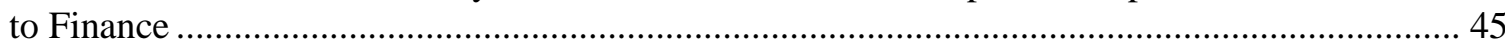

Table A.1. Heterogeneity by country \& firm type: Post-2004 EU Members \& Other

Factory Europe - Frontier vs Non-frontier............................................................................... 52

Table A.2. Heterogeneity by country \& firm type: Large \& Small Countries - Frontier vs

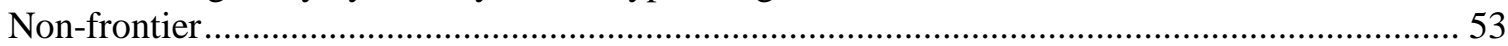

Table A.3. Heterogeneity by sector \& firm type: Manufacturing \& Services - Frontier vs ................ 53

Table A.4. Decomposition of Average Productivity (Centrality Weighted) of Buyers and

Suppliers.

Table A.5. First Stage of Indstrumental Variable Estimation ............................................................. 54

\section{Figures}

Figure 1. Bonacich-Katz Eigenvector Centrality Illustration

Figure 2. Annual Increase in MFP for Frontier and Non-Frontier Firms for mean growth in

Productivity of Buyers / Suppliers

Figure 3. Annual Increase in MFP for Larger and Smaller Firms for mean growth in

Productivity of Buyers / Suppliers

Figure 4. Annual Increase in MFP for Frontier and Non-Frontier Firms for mean growth in

Productivity of Buyers / Suppliers -Labour Market Policy 42

\section{Boxes}

Box 1.1. Technical Details of Diffusion Empirical Framework 


\title{
GVC centrality and productivity: Are hubs key to firm performance?
}

\author{
By Chiara Criscuolo and Jonathan Timmis ${ }^{1}$
}

\section{Introduction}

1. Recent years have witnessed large changes in structure of GVCs, with some manufacturing hubs shifting eastwards, whereas some services activities have become more influential for value chains almost universally (see Criscuolo and Timmis, 2018). It is well-established that GVC participation can increase productivity, however these changes in the structure of GVCs and position within them might also matter for productivity. Firms and industries positioned at the centre of complex production networks have access to a greater variety of foreign knowledge, compared to those at the periphery. Potential knowledge spillovers may be further reinforced when firms are part of networks connecting highly productive frontier suppliers or customers, with access to more advanced knowledge. Therefore whether firms and industries sit at the fringes of global production or are tightly knotted at the centre of a complex network, connecting highly productive foreign firms, is likely to affect economic outcomes.

2. This paper uses "centrality" metrics to measure position of countrysectors with Global Value Chains (GVCs) and link these changes to firm productivity. Centrality is a measure of influence or connectivity within the global production network. Central sectors reflect those that are highly connected (both

\footnotetext{
${ }^{1}$ Corresponding authors are: Chiara Criscuolo (Chiara.Criscuolo@oecd.org) and Jonathan Timmis (Jonathan.Timmis@oecd.org) from the OECD Science, Technology and Innovation (STI) Directorate. The authors would like to thank the following: Axelle Arquié (OECD Economics Department), Matej Bajgar (OECD STI Directorate), Giuseppe Berlingieri (OECD STI Directorate), Sara Calligaris (OECD STI Directorate), Flavio Calvino (OECD STI Directorate), Isabelle Desnoyers-James (OECD STI Directorate), Jana Emmenegger (OECD STI Directorate), Peter Gal (OECD Economics Department), Keiko Ito (Senshu University), Nick Johnstone (OECD STI Directorate), Kyosuke Kurita (Kwansei Gakuin University), Igor Linkov (US Army Engineer Research and Development Center), Catherine L. Mann (OECD Economics Department), Sébastien Miroudot (OECD Trade and Agriculture Directorate), Giuseppe Nicoletti (OECD Economics Department), Laurent Pauwels (University of Sydney), Dirk Pilat (OECD STI Directorate), Rudy Verlhac (OECD STI Directorate), Colin Webb (OECD STI Directorate), Andrew Wyckoff (OECD STI Directorate), Norihiko Yamano (OECD STI Directorate) and Hashiguchi Yoshihiro (IDE-JETRO) for their valuable comments. We would also like to thank seminar and conference participants at the Global Forum on Productivity Conferences in Lisbon and Budapest, KIIS Workshop, Small Advanced Economies Institute and OECD Committee Meetings and seminars. Further thanks go to Sarah Michelson (OECD Economics Department) for excellent editorial support.
} 
directly and indirectly) and influential within global production networks, and conversely, peripheral sectors exhibit weak linkages to other sectors and countries and so are less influential (see Criscuolo and Timmis, 2018). We first examine the correlation of changes in firm productivity with the shifts in the structure of GVCs, as a central supplier or customer respectively. Secondly, we examine the additional impact of being connected to increasingly productive foreign sectors (conditional on centrality). Thus, allowing us to distinguish the role of becoming a central hub (regardless of who is connected) versus connecting fast growing foreign sectors (regardless of centrality).

3. We find that the changing structure of GVCs can play a role in the catch up of firms, but that the results are heterogeneous across firms and countries. In terms of firm heterogeneity, we find that both centrality and the productivity of foreign sectors correlate with the productivity of non-frontier or smaller firms, but these correlations weaken with firm size and with proximity to the frontier. Since these smaller or less productive firms are less likely to be engaged in GVCs directly (e.g. as exporters), this suggests domestic spillovers through supply chains can play an important role in the productivity gains of GVCs. In terms of countries, centrality is correlated with average firm productivity only in smaller or post-2004 EU economies, whereas being connected to productivity foreign sectors matters more for the average firm in larger or other European economies. In addition, the policy environment, such as flexible labour markets, better access to finance, fewer barriers to entrepreneurship, stronger contract enforcement and simplified export procedures, appears to be important in translating the changing structure of GVCs into faster productivity growth of these firms.

4. Specifically, we match GVC centrality metrics at the country-industry level constructed by Criscuolo and Timmis (2018) to cross-country Orbis firmlevel data to examine the impact of changes in the structure of the GVC network on firm productivity growth. ${ }^{2}$ The Orbis data is the most comprehensive source of firm-level data available to us, although the data comprise mainly medium and large firms from high-income economies (see Bajgar et al, 2017). Therefore it is not possible to comment on the productivity of the smallest firms (those with less than 20 employees) or on how these impacts may differ for emerging economies. We use the panel structure of the data to examine how these correlations differ based on initial characteristics of firms, such as by firm size, ownership and exante productivity, and use firm location to distinguish by country characteristics, such as country size, significant changes, such as EU accession, and last but not least to analyse the role of differences in policy environments.

5. We undertake a number of robustness checks of our main results. One concern may be that picking up the effect of import competition on prices/mark-

\footnotetext{
${ }^{2}$ Specifically, we calculate PageRank version of Bonacich-Katz eigenvector centralities using the network of input flows between countries and industries detailed in the OECD Inter-Country Input-Output (ICIO) Database, 2015 edition. Centrality is decomposed into foreign and domestic origins. Foreign centrality represents the centrality due to (direct and indirect) linkages to foreign sectors and domestic centrality the component due to (direct and indirect) linkages to domestic sectors. Given the focus on GVCs, we utilise foreign centrality as our key explanatory variable, including domestic centrality as a control variable.
} 
ups in domestic sectors, rather than quantity-based productivity. We find our conclusions are robust to using a measure of mark-up adjusted MFP. Another concern might be that the presence of multinational firms (MNEs) may be contaminating the analysis. Our centrality metric is least likely to be plausibly exogenous for large multinationals, where because of their size, their import and export decisions may be able to influence their industry's centrality. Thus, for multinationals there may be reverse causality: the performance of multinationals may determine centrality, rather than the other way around. Our results are robust to excluding MNEs and their affiliates. In addition, we find our results are robust to using a variant of our baseline centrality metric with centrality parameters that vary by country-industry (as employed by Acemoglu et al, 2015 and Imbs and Pauwels, 2016) and focusing on countries with better coverage within Orbis. Finally, our results do not seem to simply be capturing changes in GVC participation over time and are unchanged using instrumental variable analysis.

6. Our work draws heavily upon the growing body of work that uses centrality metrics to describe the structure of real-world production networks. Cerina et al. (2015) compute a range of centrality metrics using WIOD inputoutput (IO) data, and find that industries are highly asymmetrically connected and also that GVCs are regionally clustered. Using the metrics employed in this paper, Criscuolo and Timmis (2018) find that there have been large changes in the organisation of some GVCs. Whereas motor vehicles manufacturing remains clustered around the same central hubs in the US and Germany, for IT manufacturing there have been dramatic shifts to Eastern. Europe and Asia and away from high-income centres of production, whereas IT services have become more central for GVCs almost universally. Several emerging economies and their industries have become more central in general to global production networks, and the growing importance of Eastern European economies coincides with the timing of their EU accession. Other papers have applied centrality metrics to trade in value-added data, rather than IO data, Amador and Cabral (2017) find that foreign value added in exports became denser, more complex and tightly connected over time and Gourdon et al. (2016) highlight the growing importance of China in electrical machinery manufacturing.

7. The literature has most often applied centrality metrics to study shock transmission and granularity, often within a single country, rather than productivity in a cross-country setting as we do here. This strand of work are based on the fact that in real-world production networks input flows are not distributed symmetrically and so well-connected agents, by linking remote parts of the network, can play a key role in the transmission of shocks (Acemoglu et al., 2012). In addition, a shock affecting these central agents does not die out in the aggregate, such that micro shocks can influence macro outcomes (Magerman et al., 2016). Research using US Input-Output tables finds that a minority of these key sectors drive a large portion of aggregate outcomes. For instance, productivity growth in the 10 most central US sectors (out of 417 sectors in the US InputOutput tables, approximately at the NAICS 4 digit level) account for $80 \%$ of the variation in US aggregate output growth over the period 1959-2009 (Carvalho, 2014). Using novel firm-to-firm transaction data for Belgium, Magerman et al. (2016), find productivity shocks to the 100 most central Belgian firms (out of 80,000 firms in their sample) account for $91.3 \%$ of Belgian aggregate volatility. Imbs and Pauwels (2016) find that GDP volatility between developed countries is 
explained by differences in foreign centrality, but not centrality due to domestic linkages, and that this link has strengthened over time.

8. A related stream of research considers the importance of centrality for the diffusion of knowledge or new technologies, often using social networks rather than production networks as in this paper. Central players by definition have a high degree of connectivity (both directly and indirectly), more widespread and closer linkages to other agents, and therefore potentially broader access to knowledge that these other agents possess. Villagers in India consistently identify the most central person in terms of both direct and indirect social linkages as the person best-placed to spread information (Banerjee et al, 2016). Students randomly allocated into groups of other students with high centrality tend to outperform those randomly allocated to groups with lower centrality (Hahn et al., 2015). Diffusion of participation in a weather insurance scheme reaches a greater proportion of farmers, when information on insurance is provided to those farmers that are more central, in terms of social linkages within the village (Caie et al, 2015). Social linkages between farmers predict the diffusion of fertiliser technology in Ghana, with farmers copying neighbours who were unexpectedly successful in prior periods (Conley and Udry, 2010). One paper using production network data, finds that US industries and firms are more likely to adopt new types of inputs when those inputs are already inputs to their current suppliers. However, as the authors acknowledge, further work is needed to uncover the precise mechanisms at play (Carvalho and Voitglänger, 2015). In the interests of parsimony, the reader is directed to Criscuolo and Timmis (2018) for a more detailed review of the literature.

9. The paper proceeds as follows. The next section briefly recaps the methodology to identify central hubs. Section 3 briefly describes the firm-level data, and section 4 introduces our empirical framework. Section 5 presents our empirical results, Section 6 examines the role of policy and the final section provides a discussion of our main conclusions.

\section{Measuring Central Hubs in GVCs: A Brief Recap}

10. This section briefly recaps the metrics we use to identify central hubs in production networks. A more comprehensive discussion of the Bonacich-Katz eigenvector centrality metric adopted in the paper is detailed within Criscuolo and Timmis (2018).

11. We employ measures of Bonacich-Katz eigenvector centrality, which take into account both direct and indirect linkages to identify key hubs. Centrality is a measure of influence or connectivity within the global production network. Central sectors reflect those that are highly connected (both directly and indirectly) and influential within global production networks, and conversely, peripheral sectors exhibit weak linkages to other sectors and countries and so are less influential. Thus centrality is determined not only based on direct trade linkages, but also the linkages of a country trade partners, and the trade partners of the trade partners and so on. ${ }^{3}$ In the simplified production network of Figure 1,

\footnotetext{
${ }^{3}$ These metrics have recently been applied to identify key players in several literatures, as noted earlier, including the macroeconomic research on shock diffusion (e.g. Acemoglu et
} 
$\mathrm{C}$ has the highest strength of direct connections and $\mathrm{B}$ has the second highest. However, eigenvector centrality reflects the strength of both direct and indirect linkages. Although A only has two direct linkages (to B and $\mathrm{C}$ ), it has five linkages one-indirect linkage away (D to $\mathrm{H}$ ). A is a key hub in the network and would have highest centrality.

12. Bonacich-Katz eigenvector centrality for each sector in a particular country is calculated as a baseline centrality, plus a weighted sum of centralities of their trade partners. Thus, Bonacich-Katz eigenvector centrality is a recursive relationship, where centrality is inherited from your partners. A given sector is central because it trades with central hubs and vice versa. But crucially not all customers/suppliers of a key hub benefit equally, the "inheritance" is weighted by how important they are to the key hub. The centrality is higher for sectors that are major customers/suppliers of a central hub than those that are minor customers/suppliers. Therefore both who you trade with (central hubs or peripheral sectors) and the strength of those trading relationships determines your centrality.

13. One implication of the measure, is that it is a relative centrality. The mean country-industry centrality in each year is equal to unity in each year, as noted in Criscuolo and Timmis (2018). One implication is that centrality is not an absolute measure, but rather a relative measure, relative to other country-industries in the network. One advantage of this is that the centrality metric has a consistent unit of measurement. However, it does require care to interpret changes in centrality over time, meaning increasing/decreasing influence relative to others in the network. For example, increasing centrality could in principle be because you are more influential in absolute terms or because peers in the network have become less influential. Consequently our empirical analysis compares across countryindustries in the network, rather than within them (which is discussed in the later empirical framework).

14. The centrality metrics we use distinguish between key suppliers and key customers, using forwards and backwards linkages respectively. Countries and industries can be central because of their linkages to domestic sectors or linkages to foreign sectors: given our concern with GVCs, this paper focuses on the foreign component of centrality. The domestic component of centrality, nevertheless, is included as a control variable in our regressions.

15. The centrality metrics we use are derived from the 2015 edition of the OECD-ICIO data that underlies the OECD-WTO TiVA indicators. The data employed here contain rich inter-country information, reflecting input flows of goods and services both across and within 62 economies (including the Rest of the World) for the period 1995-2011. These flows are disaggregated across 34 ISIC rev. 3 sectors, comprising manufacturing, services and industrial activities. There are two key advantages to these data. Firstly, they have a broad coverage of the main actors in global production networks, with a comprehensive coverage of European, North American and Asian economies in particular. Secondly, this reflects flows of services as well as goods, with the former not captured for

al., 2012; Carvalho, 2012; 2014), and more broadly to knowledge diffusion in social networks (Alatas et al., 2016; Banerjee et al., 2016). 
instance in network analysis of customs data (e.g. De Benedictis et al, 2013). Although the relatively broad definition of sectors in the ICIO data is a limitation of the analysis.

Figure 1. Bonacich-Katz Eigenvector Centrality Illustration

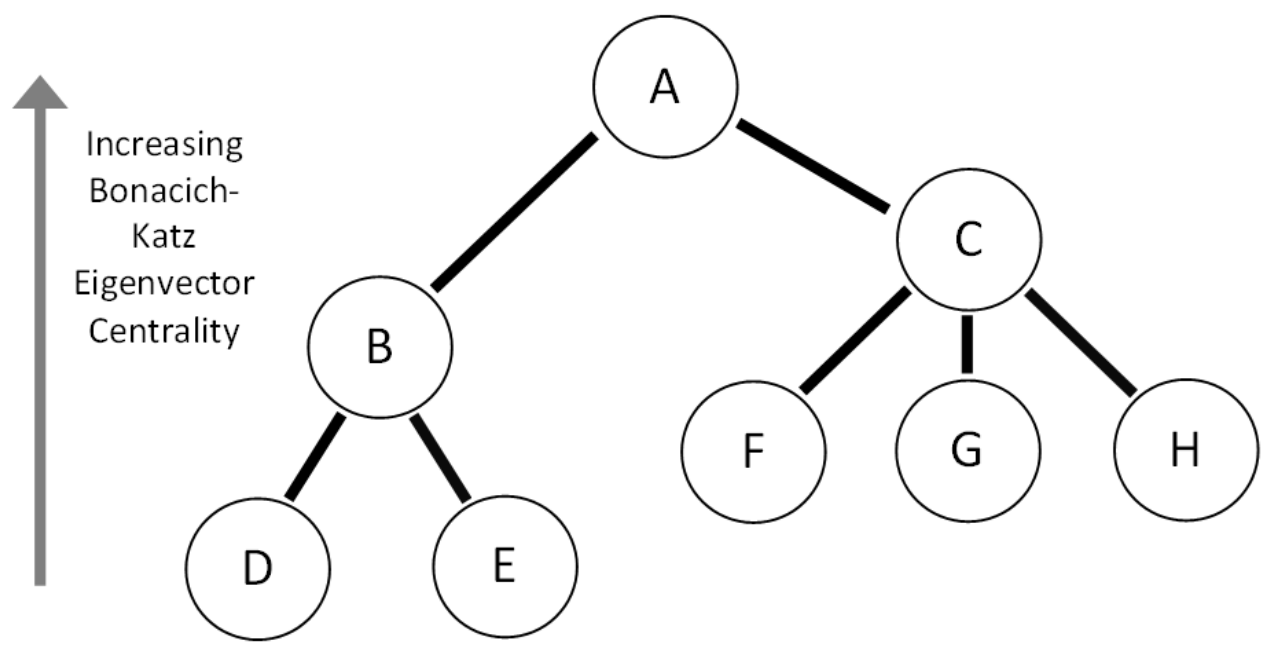

\section{Firm-Level Data Description}

16. This section presents a brief overview of the Orbis firm-level data used as the measure of firm productivity, our cleaning procedures and summary statistics.

17. Orbis is a harmonised cross-country dataset provided to the OECD by Bureau Van Dijk. To fully exploit our cross-country and cross-industry centrality measure, we use a broad coverage of countries and industries, retaining all countries with more than 500 (firm-year) observations in the matched data ${ }^{4}$. This results in data that mainly reflects OECD economies, with data for 24 OECD economies and 4 non-OECD economies ${ }^{5}$, therefore it is not possible to examine how our results differ for emerging economies. The industry detail is at the 2-digit in NACE rev. 2 and comprise the non-farm non-financial business sector excluding mining, petroleum manufacturing and real estate activities (i.e. codes 10-82, excluding 19, 64-66 and 68). Orbis has relatively poor coverage of small firms, therefore we restrict the sample to firms with more than 20 employees (on average over the sample period).

18. We undertake a number of cleaning steps, closely following the suggestions by Kalemli-Ozcan, et al. (2015) and previous OECD analysis (Gal,

${ }^{4}$ In later robustness analyses we further restrict this to countries with more than 5000 observations, following Bajgar et al (2017).

${ }^{5}$ OECD economies are Australia, Austria, Belgium, Denmark, Estonia, Finland, France, Germany, Hungary, Ireland, Italy, Japan, Korea, Latvia, Luxembourg, Netherlands, Poland, Portugal, Spain, Sweden, Slovenia, Turkey, the United Kingdom and the United States. Non-OECD economies are Bulgaria, China, India and Romania. 
2013; Andrews et al., 2016). As discussed in Gal and Hijzen (2016) and Andrews et al. (2016), these data are cleaned and benchmarked using a number of common procedures such as keeping accounts that refer to entire calendar year, using harmonized consolidation level of accounts, dropping observations with missing information on key variables as well as outliers identified as implausible changes or ratios. We focus on unconsolidated accounts, out of a concern that consolidated financial accounts may consolidate firm information from different industries and/or countries. To extend coverage, value-added has been internally imputed using the factor incomes given within Orbis, i.e. the cost of employees and earnings before interest, taxes, depreciation and amortisation, as suggested by Gal (2013). Nevertheless, a number of issues that commonly affect productivity measurement should be kept in mind, including: i) differences in the quality and utilisation of inputs cannot be accounted for as the capital stock is measured in book values; ii) firm-level prices cannot be observed ${ }^{6}$, so firm-level differences in measured productivity may also reflect differences in market power ${ }^{7}$; and iii) measuring outputs and inputs in internationally comparable price levels remains an important challenge when comparing productivity levels across countries ${ }^{8}$.

19. We match firm-level Orbis data to the centrality metrics calculated using OECD ICIO data, using a firm's country, NACE rev. 2 industry code and year. We employ a concordance between 2 digit NACE rev. 2 and 34 TiVA (ISIC rev. 3) industries to account for differing industry definitions between Orbis and OECD ICIO data. The OECD ICIO data are available over 1995-2011, which ultimately determines the number of years of our analysis. As noted in our empirical framework, we use one year lagged values of centrality, meaning that our period of analysis is 1996-2012.

20. The firms included in the final sample are predominantly of medium to large in size and are older firms, with a mean employment of 260 employees and a mean age of 22 years (see Table 1). Therefore it is not possible to comment on the productivity of the smallest firms. Just under half these firms are in the manufacturing sector, reflecting that Orbis tends to have better coverage of manufacturing firms (Bajgar et al., 2017).

Table 1. Summary Statistics of Firm-Level Data

\begin{tabular}{|c|c|c|c|}
\hline & Mean & Std. Dev & $\mathrm{N}$ \\
\hline MFP (logs) & 10.9 & 1.0 & $2,446,048$ \\
\hline Employment (number) & 260 & 3485 & $2,446,048$ \\
\hline Sales (PPP\$ millions) & 83.3 & 1090.9 & $2,446,048$ \\
\hline
\end{tabular}

\footnotetext{
${ }^{6}$ However, in our case not observing firm-level prices is less problematic, since our main explanatory variables vary at same level as the deflators we apply, i.e. at the industrylevel.

${ }^{7}$ As noted in the empirical framework, we examine robustness of our analysis to mark-up adjusted MFP following the approach of De Loecker and Warzynski (2012).

${ }^{8}$ Monetary variables are deflated using 2-digit industry deflators from OECD STAN and national accounts and prices are expressed in industry purchasing power parities (PPPs), using the country-industry level purchasing power parity database of Inklaar and Timmer (2014).
} 


\begin{tabular}{|c|c|c|c|}
\hline Age (years) & 21.6 & 18.0 & $2,415,859$ \\
\hline Services & 0.54 & 0.50 & $2,446,048$ \\
\hline
\end{tabular}

Note: Age is not included as a control variable in the regressions reported in the remainder of the paper as it is collinear with firm fixed effects, but is included in this table for information purposes.

\section{Empirical framework}

21. In this section we outline our approach to examining how centrality affects the diffusion of productivity across firms, sectors and economies. We focus on how productivity changes in foreign sectors diffuse through key hubs to influence the productivity of domestic firms. We consider two aspects of this diffusion, as noted in Box 1.1. The first reflects the role of becoming a central hub (regardless of which sectors are connected), and the second, the role of connecting fast growing foreign sectors (regardless of centrality). We measure the former using the centrality metric explained earlier and the latter using the average productivity (centrality weighted) of buyers / suppliers (as noted in Box 1.1).

22. We first examine whether becoming more central within GVCs translates into changes in firm productivity. Specifically, we consider whether firms in industries that become more central over time, increase productivity faster than those in industries that become more peripheral. As noted in the introduction, central hubs play a key role in linking agents throughout the network. Central hubs by definition have a high degree of connectivity (both directly and indirectly), more widespread and closer linkages to other buyers and suppliers, and therefore potentially broader access to knowledge that these other agents possess. An emerging literature shows that central hubs play a key role in the transmission of shocks, both domestically and across borders. One may expect that central hubs may also facilitate the transmission of knowledge. As noted earlier centrality is a measure of influence within a network. This first metric therefore reflects whether becoming more or less influential within GVC networks matters for firm productivity.

23. Secondly, we examine whether who an industry connects to matters for firm productivity. We measure whether firms have faster productivity increases in industries connected to faster growing foreign buyers or suppliers. The diffusion path of new knowledge is unlikely to be determined solely by influence within GVC networks, but rather those sectors that are highly connected to new sources of knowledge are likely to benefit more. For instance, a key hub connecting highly productive, technologically advanced foreign buyers and suppliers is likely to have greater access to knowledge than a key hub connecting less productive ones. The diffusion of foreign knowledge may therefore depend upon the composition of buyer / supplier connections. We reflect this with the (centrality weighted) average productivity of foreign buyers / suppliers. The latter therefore reflects whether the productivity of a sector's more influential buyers or sellers matters for firm productivity.

24. The empirical framework estimates the within-firm productivity role of sector centrality and the role of being connected to more productive (foreign) sectors. Firstly, it measures whether firms have faster productivity increases within sectors that become more central, compared to those that become more 
peripheral ${ }^{9}$. Secondly, it also reflects whether increases in the productivity of foreign sectors translates into changes in productivity of firms in sectors that are connected to them.

$$
\begin{gathered}
\text { MFP }_{\text {ist }}=\beta_{1} c_{s t-1}+\beta_{2} \overline{\text { PROD }}_{\text {st-1 }}+\beta_{3} \text { Industry Controls }_{\text {st }-1} \\
+\beta_{4} \text { Firm Controls }_{\text {st }-1}+\delta_{i}+\delta_{t}+\varepsilon_{\text {ist }}
\end{gathered}
$$

where $M F P_{\text {ist }}$ refers to the Multi Factor Productivity of firm i, in country-sector s and time t. $c_{s t-1}$ is the centrality of country-sector $\mathrm{s}$, which is lagged one period, and refers to either total, forwards or backwards centrality in the results below. $\overline{P R O D}_{s t-1}$ is the average productivity (centrality weighted) of foreign buyers / suppliers, lagged one period, and refers to either total, forwards or backwards linkages. Industry controls include domestic sources of centrality, total (forwards and backwards) GVC participation, Fally's (2011) GVC upstreamness and GVC length measures, Industry exports of intermediate goods and services, Industry imports of intermediate goods and services, Industry gross output (as a measure of industry size), Balassa's Gross Revealed Comparative Advantage, and Koopman et al.'s (2014) Value-Added Revealed Comparative Advantage. Lagged firm employment is included as a control for firm size; firm age is not included since it is reflected in the firm fixed effects as the model includes both firm and year fixed effects $\left(\delta_{i}\right.$ and $\delta_{t}$ respectively).Robust standard errors are clustered at the country-industry level, where industry reflects the $34 \mathrm{TiVA}$ industries underlying the centrality measure.

25. The inclusion of both firm and year fixed effects means we are comparing within firm changes in productivity, due to industry-level changes in centrality or changes in productivity of their suppliers/customers. The firm fixed effects control for any time-invariant firm (and thus also industry and/or country) characteristics and year fixed effects control for any time-variant factors common across firms. We therefore reflect within-firm changes based on changes in centrality across country-industries.

26. We do not include country-year or industry-year fixed effects to ensure the impact of centrality is estimated across country-industries. As noted earlier, centrality is inherently a relative measure, such that it is relative to all other countries and industries in the network at a particular point in time. Since centrality has a mean value of one each time period, comparisons over time for the same country-industry need to be interpreted cautiously, since if one countyindustries centrality increases, then by definition another must fall. Therefore the appropriate comparison is one country-sector against another. Including further fixed effects in equation 1, such as industry-year or country-year dummies, would depart from this comparison. For example, including industry-year dummies would mean we are measuring changes across countries but within the same industry and year (e.g. computing and electronics manufacturing in 2000). Instead, we follow the approach of Imbs and Pauwels (2016) and do not include further fixed effects, but instead introduce a broad range of industry controls reflecting factors that may explain any link between centrality and firm

\footnotetext{
${ }^{9}$ As discussed below, the inclusion of both firm and year fixed effects means we are examining within firm changes in productivity.
} 
productivity. For example, one would expect that exports, imports and gross output should reflect variations in the business cycle that may impact both GVCs and productivity. 


\section{Box 1.1. Technical Details of Diffusion Empirical Framework}

We consider two aspects in our analysis of productivity diffusion. The first reflects the role of becoming a central hub (regardless of which sectors are connected), and the second, the role of connecting fast growing foreign sectors (regardless of centrality).

The first aspect is captured by the centrality measure elaborated in the first part of this paper. The second aspect is reflected by the (centrality weighted) average productivity of foreign buyers / suppliers and is discussed further below.

For each country-industry we can decompose all country and industry sources of backwards and forwards centrality and reflect the sources of influence of a country-sector on the GVC network. For example, in terms of countryindustry i's backward (foreign) centrality, we can write as:

$$
c_{i}^{\text {back }}=\sum_{j \in f g n} c_{-} \text {source }_{i j}^{\text {back }}
$$

where $c_{-}$source $_{i j}$ are the foreign sources of backwards centrality, which are technically defined as (foreign) elements $\mathrm{ij}$ of the inverse matrix given by $\eta\left(\mathbf{I}-\lambda \mathbf{W}^{\mathbf{T}}\right)^{-1}$ see Criscuolo and Timmis (2018).

We measure the average productivity of foreign suppliers or customers using sources of centrality as weights. Since centrality is a measure of influence within the GVC network, this reflects the productivity of a sector's more influential foreign buyers and suppliers. Intuitively, productivity is assumed to diffuse more strongly between sectors that are more influential on one another, and less strongly from/to sectors that are more peripheral.

$$
\overline{P R O D}_{i}^{\text {back }}=\sum_{j \in f g n}\left(\text { c_source }_{i j}^{\text {back }} /{ }_{c_{i}^{\text {back }}}\right) \cdot \operatorname{Prod}_{j}
$$

Where $\overline{P R O D}_{i}^{\text {back }}$ is the (centrality weighted) average productivity of foreign suppliers of country-sector $\mathrm{i}$ and $\operatorname{Prod}_{j}$ is the productivity of each foreign country-sector supplier $\mathrm{j}$, and the term in parentheses is the backward linkage centrality weights (that sum to one). To remove noise, we measure each foreign sector's productivity as the 3 year moving average of log labour productivity (value-added per worker in international PPP dollars).

Similarly we can write the (centrality weighted) average productivity of foreign customers:

$$
\overline{P R O D}_{i}^{f w d}=\sum_{j \in f g n}\left(c_{-} \text {source }_{i j}^{f w d} /{ }_{c_{i}^{f w d}}\right) \cdot \operatorname{Prod}_{j}
$$

Where $\overline{P R O D}_{i}^{f w d}$ is the (centrality weighted) average productivity of foreign buyers of country-sector $\mathrm{i}$ and $\operatorname{Prod}_{j}$ is the productivity of each foreign country-sector buyer $\mathrm{j}$, and the term in parentheses is the forward linkage centrality weights (that sum to one). 
27. In the baseline specification MFP is estimated using the IV method proposed by Wooldridge (2009), and to allow for technological differences across industries and countries, the production function is estimated separately for each 2-digit industry, controlling for country fixed effects. Estimation uses a real value added based production function estimation with the number of employees and real capital as inputs (deflated using 2 digit country-specific deflators). However, there is a large literature examining how imports can affect competition in domestic markets and hence firm mark-ups. Therefore one concern might be that centrality may affect firm mark-ups (through competition) differently to physical or quantity-based MFP (through knowledge diffusion). In robustness analysis we control for unobservable firm markups using the method of De Loecker and Warzynski (2012) to report mark-up adjusted firm MFP.

28. Another potential concern is that the network of input linkages underlying our measures may not be exogenously determined. Firstly, since more productive firms tend to trade more intensively and with more countries and trade partners (e.g. Bernard et al, 2011b; 2014), productivity increases themselves may lead to increased centrality within the GVC network, rather than the other way round. Secondly, domestic productivity may affect the composition of trade partners. Increases in productivity may result in more intensive connections to more productive foreign sectors. For example, evidence suggests firms do not select their trade partners at random, but are more likely to trade with more productive foreign firms (since only the most productive firms import or export). Similarly, more productive economies tend to produce higher quality goods, which often require higher quality foreign inputs and these are often supplied by more productive foreign firms (Bas and Strauss-Kahn, 2015; Atkin et al. 2017). Finally, if firms can benefit from knowledge spillovers from productive foreign sectors, one may expect firms to actively choose to trade with such sectors. Thus, any productivity impacts on firms may not be because of diffusion of knowledge through the network, but the endogenous formation of network linkages to yield such correlations.

29. Firstly, we address the potential endogeneity concern using sample restrictions. The use of firm-level data and industry-level centrality measures reduces the scale of the problem, as it is unlikely that many firms are able to influence the centrality of their entire industry within the GVC network. Centrality of the industry is therefore likely to be exogenous from a firm perspective, especially when considering small and medium sized firms. However, a minority of highly productive firms often account for the bulk of input flows across borders and a minority of multinationals are often found to drive GVCs (De Backer et al., 2017). To mitigate this concern, we examine our results separately for different firm types, isolating whether the productivity correlations are driven by a minority of these frontier firms that may be able to influence industry centrality or those smaller and medium-sized firms, far from the frontier, that are less likely to be able to influence industry metrics. In addition, we use the ownership information within Orbis to exclude multinationals and their affiliates in robustness analyses. The coverage within the ownership data varies over time, accordingly we exclude those firms that are ever (in any year) identified as a multinational or an affiliate in the data.

30. In addition, we use instrumental variables to predict the exogenous effects of our variables of interest. In terms of our first variable, centrality, we use lagged 
values as a predictor. Since our specification already uses centrality lagged one period, we use centrality lagged three periods as an instrumental variable. Thus we are measuring the effect of centrality, due to historic changes, rather than any contemporaneous technology shocks that may lead to both increases in productivity and reorganisation of value chains. In terms of the productivity of buyers / suppliers, we use the initial structure of an industry's foreign buyer and supplier networks to construct the weights but current values of their foreign productivity. Thus we are measuring the effect of contemporaneous changes in foreign productivity, taking the network of buyers and suppliers as fixed over the period.

31. Another concern may be related to coverage limitations within the Orbis data. Although Orbis is the most comprehensive source of cross-country firmlevel data available to us, the coverage varies substantially across countries. In the baseline analysis, we include only countries with at least 500 observations in the matched data. As a robustness check we restrict the sample to countries with at least 5000 observations, following Bajgar et al (2017), which leads to a sample of 19 countries (from 28 in the baseline).

32. In addition, we examine robustness of our results to using a variant of our main centrality metric, which is instead calculated using country-industry varying parameters. In the centrality metric, direct connections are given more importance than higher-order indirect connections, and one of the key parameters determines the extent of this decay in importance as connections become more indirect. In the main analysis we employ the centrality metric constructed by Criscuolo and Timmis (2018), which employs constant parameters across all countries and industries, a standard approach in the network literature. Some authors have instead calculated centrality using parameters that vary by country and industry (such as Imbs and Pauwels, 2016; or Acemoglu et al, 2015) ${ }^{10}$. We examine robustness of our results using this variant of our main centrality metric.

33. A final concern might be that the changes in centrality are simply reflecting changes in GVC participation. Centrality metrics are complementary to measures of GVC participation, which reflect the use of foreign value-added in exports. Participating in GVCs to some degree is clearly a pre-requisite of being central. Analyses presented within Criscuolo and Timmis (2018) showed a weak positive correlation between these two metrics, such that centrality and participation are not equivalent. We supplement the inclusion of GVC participation metrics as control variables, by also contrasting the centralityweighted average productivity of buyers / suppliers with the foreign value-added weighted (GVC participation weighted) average productivity.

10 Specifically, the parameter $\lambda$ which determines the rate of decay of higher order network linkages is given by each country-industry's share of intermediates in production (rather than the average across all country-industries in the baseline specification), and $\eta$ is defined as $1-\lambda$ as in the baseline (see Criscuolo and Timmis, 2018 for more discussion of these parameters). 


\section{Empirical Results}

34. In this section we present our empirical results on how productivity changes in foreign sectors diffuse through key hubs to influence the productivity of domestic firms. We consider two aspects as noted earlier, the first reflects the role of becoming a central hub (regardless of which sectors are connected), and the second, the role of connecting fast growing foreign sectors (regardless of centrality). We first present our baseline results, for all firms in the sample. Secondly, we examine various aspects of heterogeneity: by firm size / productivity, by country and by sector.

\section{Baseline Results}

35. This section presents the baseline empirical results, examining the correlations with changes in firm productivity for the "average" firm in our sample.

36. In terms of centrality, firms within sectors that become increasingly central do not tend to show faster productivity increases than firms in sectors that become more peripheral. Table 2 presents the baseline estimates of equation 1 , examining the correlations between changes in (foreign) centrality and productivity of foreign suppliers / buyers on domestic firm productivity. We find no evidence of any correlation between firm productivity and centrality, across both total centrality (column 1), as well as decomposing into centrality as supplier (forwards linkages - column 3) or as customer (backwards linkages - column 5), or even including a broad range of industry controls (columns 2, 4 and 6). Thus becoming a key hub or becoming more peripheral does not seem to be correlated with changes in firm productivity on average.

37. However, changes in the (centrality weighted) average productivity of buyers / sellers does seem to be associated with firm productivity of the average firm (see Table 2, columns 1 and 2). A 1\% increase in the productivity of foreign buyers/suppliers is correlated with a $0.6 \%$ increase in productivity of domestic firms (see column 2$)^{11}$. Decomposing total connections into those forwards and backwards, shows that what matters are forward linkages, i.e. forwards linkages as a supplier to more productive foreign buyers (columns 3 and 4). This is consistent with the notion that productive foreign buyers share knowledge with their suppliers, backwards through the value chain. A large literature on the productivity effects of FDI finds similar mechanisms, with evidence of spillovers from multinationals to their affiliate suppliers, with less evidence of forwards spillovers to their customers, (Godart and Görg, 2013; Havránek and Iršova, 2011) similar mechanisms are also evident from the literature looking at the sources of knowledge for importers and exporters, with inventions of importers being significantly more likely to be influenced by foreign technology than are the inventions of firms that do not imporwith importers' patent. This is not the case for exporters (McGarvie, 2006).

\footnotetext{
${ }^{11}$ For information, in our sample, the mean annual growth in the average productivity (centrality weighted) of foreign buyers / suppliers over 1995-2011 is $0.9 \%$.
} 
38. In contrast, we find no evidence of correlations with the average productivity of suppliers (via backwards linkages) (see Table 2, columns 5 and 6). Thus using inputs from more productive foreign sectors does not seem to translate into domestic productivity gains. This latter result, might appear counterintuitive and in contrast with evidence on input liberalisation, suggesting that importing high quality inputs can lead to productivity gains of domestic firms (e.g. Amiti and Konings, 2007). However, this evidence is mainly based on data for emerging economies, whereas our sample of firms are mainly from high-income countries, that may have pre-existing sources of high technology inputs. These results are again robust to including a range of industry controls in columns 2, 4 and 6. 
Table 2. Baseline Results

\begin{tabular}{|c|c|c|c|c|c|c|}
\hline \multirow[t]{2}{*}{ MFP Wooldridge } & \multirow{2}{*}{\multicolumn{2}{|c|}{ Total }} & (3) & \multirow{2}{*}{ rd } & \multirow{2}{*}{\multicolumn{2}{|c|}{ (5) Backward }} \\
\hline & & & Forward & & & \\
\hline Centrality & $\begin{array}{l}-0.039 \\
(0.087)\end{array}$ & $\begin{array}{c}0.237 \\
(0.148)\end{array}$ & $\begin{array}{l}-0.036 \\
(0.075)\end{array}$ & $\begin{array}{c}0.046 \\
(0.090)\end{array}$ & $\begin{array}{c}0.002 \\
(0.060)\end{array}$ & $\begin{array}{c}0.144 \\
(0.089)\end{array}$ \\
\hline $\begin{array}{l}\text { Average Productivity (Centrality } \\
\text { Weighted) of Buyers / Suppliers }\end{array}$ & $\begin{array}{l}0.707^{\star * *} \\
(0.199)\end{array}$ & $\begin{array}{c}0.637^{* * *} \\
(0.139)\end{array}$ & $\begin{array}{l}0.882^{* * *} \\
(0.246)\end{array}$ & $\begin{array}{l}0.888^{* * *} \\
(0.204)\end{array}$ & $\begin{array}{l}0.187 \\
(0.155)\end{array}$ & $\begin{array}{l}0.092 \\
(0.164)\end{array}$ \\
\hline Observations & $2,446,048$ & $2,446,048$ & $2,446,048$ & $2,446,048$ & $2,446,048$ & $2,446,048$ \\
\hline YEAR FE & Y & Y & $\mathrm{Y}$ & $\mathrm{Y}$ & Y & $\mathrm{Y}$ \\
\hline FIRM FE & Y & Y & Y & Y & Y & Y \\
\hline FIRM SIZE CONTROLS & Y & Y & Y & Y & Y & Y \\
\hline INDUSTRY CONTROLS & $\mathrm{N}$ & $\mathrm{Y}$ & $\mathrm{N}$ & Y & $\mathrm{N}$ & Y \\
\hline
\end{tabular}

\section{Heterogeneity - Which Firms?}

39. The previous section examined productivity correlations for the "average" firm, however, it is not necessarily true that these correlations will be homogenous across firms ${ }^{12}$. Further, if positive correlations are present for only a subset of firms, they may not be revealed in the previous section. A priori it is unclear which subset of firms this might be. On the one hand, frontier firms are more likely to be directly engaged in GVCs through trade and FDI linkages, so will have the greatest direct exposure to foreign technologies. These larger firms are also more likely to be able to overcome the sunk costs of the complementary organisational investments needed to benefit from exposure to new technologies (see for example Brynjolfsson and Hitt, 2000). On the other hand, those firms further from the frontier are most likely to have the largest catch-up potential productivity gains from knowledge spillovers from foreign sectors.

40. In this section we examine whether there are heterogeneous impacts by firm productivity and firm size ${ }^{13}$. We measure these firm characteristics at the start of the period, since these characteristics may be influenced by changes in the trade network over time. Initial firm size is measured with both employment and sales, with MFP reflecting initial productivity. One caveat to reaffirm with the firm size measure is that these data contain mainly medium and large firms, therefore we are not able to comment on small or micro firms. As a simple measure of heterogeneity, these initial firm characteristics are interacted with the two variables of interest: our centrality measure and the average (centrality

\footnotetext{
${ }^{12}$ Monetary variables are deflated using 2-digit industry deflators from OECD STAN and national accounts and prices are expressed in industry purchasing power parities (PPPs), using the country-industry level purchasing power parity database of Inklaar and Timmer (2014).

${ }^{13}$ Young firms are not well represented in our firm-level ORBIS data, limiting the ability to disentangle heterogeneous effects by age dimensions.
} 
weighted) productivity of buyers / suppliers. The non-interacted term therefore captures correlation for smaller or non-frontier firms, whereas the interaction captures additional impact of centrality for larger firms or more productive firms.

41. In terms of the first measure, centrality, the baseline specification of the previous section suggested there was no evidence of a correlation between centrality and firm productivity on average. Table 3 shows that this average result masks substantial heterogeneity across firm types for backwards centrality (becoming a key customer), with the fastest productivity increase for those furthest from the frontier (columns 1 and 3). However this is significantly weaker for more productive firms. Assuming this correlation weakens in a linear fashion (as assumed by our specification) suggests that this correlation becomes negative for the 20 per cent most productive, frontier firms in the sample. Note this relationship seems to be present only for backwards centrality, but not forwards centrality (as a key supplier, see column 2).

42. However, the heterogeneous impacts are not quite as clear cut using size as compared to initial firm productivity above; with stronger evidence using sales, rather than employment as a size measure. Using firm sales as a measure of size suggests the productivity increase of smaller firms is positively correlated with their sector becoming more backwards or forwards central (as a key customer or supplier - columns 5 and 6). This correlation weakens for larger firms. Assuming this correlation weakens linearly suggests this correlation is negative for the 7 to 16 per cent largest firms in the sample, using backwards and forwards measures respectively. There is more limited evidence of heterogeneous impacts using employment as an alternative measure of size (columns 7 to 9).

43. In terms of the second measure, average productivity (centrality weighted) of buyers / sellers, the earlier baseline specification showed strong evidence that being connected to more productive foreign buyers (via forward linkages) is associated with domestic firm productivity. However, the average result again hides heterogeneous impacts across firms of different types, with evidence that these positive correlations are concentrated within those least productive firms, with the correlations weakening for those closer to the frontier (see columns 1 and 3 ). For non-frontier firms, we also find that their productivity is correlated with being connected to more productive foreign suppliers (via backwards linkages column 2). However, for non-frontier firms the correlations via forwards linkages are stronger than backwards linkages, mirroring the baseline results for the "average firm".

44. Looking at firms of different size, suggests that being connected particularly to more productive foreign buyers, but also foreign suppliers, matters for the productivity of smaller firms. Using firm sales as a measure of size, suggests smaller firms have faster productivity increases when connected to faster growing foreign buyers (via forward linkages) or foreign suppliers (via backward linkages), with those correlations weakening for larger firms (columns 4 to 6). Again we find these impacts are stronger for forwards linkages than for backwards linkages. This is broadly mirrored using employment as a measure of size, where similar, but weaker correlations are found (columns 7 to 9).

45. An alternative way to measure heterogeneity is to examine the correlations across different categories of firms, e.g. the largest $25 \%$, smallest $25 \%$ of firms etc. The prior analysis assumed that the correlations decayed 
linearly with firm size or initial productivity, here we allow for differential correlations across different categories of firm types. We segment the sample into quartiles based on initial firm characteristics, showing for example, the bottom quartile ( $25 \%$ least productive firms), $25-50^{\text {th }}$ percentiles, $50^{\text {th }}-75^{\text {th }}$ percentiles and the top quartile (those above the $75 \%$ most productive firms). We similarly decompose our two measures of firm size into quartiles of the relevant distribution. These dummy variables are interacted with our variable of interest: the productivity of buyers / sellers. Unfortunately, the estimation of the former variable, centrality, is too imprecise to identify separate correlations for each quartile, which probably reflects the relatively limited coverage of Orbis data of smaller firms, far from the frontier. One caveat to highlight is that since we only retain firms with more than 20 employees (on average over the sample period), our analysis distinguishes between medium and larger firms, rather than small and micro firms.

46. The heterogeneity for firms of different productivity categories (frontier vs non-frontier) are shown in Figure 2. We report the estimated productivity correlations for frontier and non-frontier firms, assuming the mean productivity growth of foreign buyers and sellers (using total linkages - both buyers and sellers) ${ }^{14}$. For frontier firms, the top quartile of most productive firms in our sample, their estimated productivity increase appears to be no different when connected to faster growing buyers and sellers. When looking beyond the frontier, we find a positive coefficient only for those furthest away from the frontier in our sample, with an estimated firm productivity increase of just over $1 \%$ per annum. The figure also shows that the association weakens with proximity to the frontier in a broadly linear fashion, supporting our earlier approach in Table 3. Firm size shows similar results (see Figure 3). Again, we fail to find any positive correlation for the largest firms, but for those smaller firms in our sample, the mean productivity growth of buyers and sellers relates to an increase in estimated firm productivity of just less than $1 \%$ per annum.

\footnotetext{
${ }^{14}$ In our sample, the mean annual growth in the average productivity (centrality weighted) of foreign buyers / suppliers over 1995-2011 is $0.9 \%$.
} 
Table 3. Heterogeneity by firm type: Frontier vs Non-frontier and Large vs Small

\begin{tabular}{|c|c|c|c|c|c|c|c|c|c|}
\hline \multirow{3}{*}{ MFP Wooldridge } & \multicolumn{3}{|c|}{ Frontier vs Non-Frontier } & \multicolumn{3}{|c|}{ Large vs Small Size (Sales) } & \multicolumn{3}{|c|}{ Large vs Small Size (Employment) } \\
\hline & (1) & (2) & (3) & (4) & (5) & (6) & (7) & (8) & (9) \\
\hline & Total & Forward & Backward & Total & Forward & Backward & Total & Forward & Backward \\
\hline \multirow[t]{2}{*}{ Centrality } & $1.336^{\star \star}$ & $0.541^{*}$ & $1.690^{* *}$ & $1.263^{\star *}$ & $0.578^{* *}$ & $1.294^{\star \star}$ & $0.358^{\star \star}$ & $0.240^{*}$ & 0.116 \\
\hline & $(0.641)$ & $(0.318)$ & $(0.654)$ & $(0.499)$ & $(0.233)$ & $(0.583)$ & $(0.171)$ & $(0.142)$ & $(0.102)$ \\
\hline \multirow[t]{2}{*}{ Centrality * Initial Firm MFP } & $-0.108^{\star *}$ & -0.045 & $-0.144^{\star \star \star}$ & & & & & & \\
\hline & $(0.053)$ & $(0.029)$ & $(0.053)$ & & & & & & \\
\hline \multirow[t]{2}{*}{ Centrality * Initial Firm Size } & & & & $-0.065^{\star *}$ & $-0.033^{* *}$ & $-0.070^{\star *}$ & $-0.030^{*}$ & -0.023 & -0.016 \\
\hline & & & & $(0.025)$ & $(0.015)$ & $(0.031)$ & $(0.016)$ & $(0.019)$ & $(0.012)$ \\
\hline \multirow{2}{*}{ Average Productivity (Centrality Weighted) of Buyers / Suppliers } & $6.173^{\star \star \star}$ & $6.312^{\star \star \star}$ & $4.994^{\star \star \star}$ & $3.556^{\star \star *}$ & $3.542^{\star * *}$ & $2.728^{\star \star \star}$ & $0.768^{\star \star \star}$ & $1.194^{\star * \star}$ & 0.045 \\
\hline & $(0.656)$ & $(0.570)$ & $(0.617)$ & $(0.422)$ & $(0.400)$ & $(0.358)$ & $(0.183)$ & $(0.311)$ & $(0.235)$ \\
\hline \multirow{2}{*}{$\begin{array}{l}\text { Average Productivity (Centrality Weighted) of Buyers / Suppliers } \\
\text { * Initial Firm MFP }\end{array}$} & $-0.507^{\star \star \star}$ & $-0.498^{\star \star \star}$ & $-0.447^{\star \star \star}$ & & & & & & \\
\hline & $(0.057)$ & $(0.052)$ & $(0.054)$ & & & & & & \\
\hline \multirow{2}{*}{$\begin{array}{l}\text { Average Productivity (Centrality Weighted) of Buyers / Suppliers } \\
\text { * Initial Firm Size }\end{array}$} & & & & $-0.180^{* * *}$ & $-0.164^{* * *}$ & $-0.162^{\star \star *}$ & -0.032 & $-0.077^{\star *}$ & 0.013 \\
\hline & & & & $(0.023)$ & $(0.022)$ & $(0.022)$ & $(0.020)$ & $(0.035)$ & $(0.023)$ \\
\hline Observations & $2,446,048$ & $2,446,048$ & $2,446,048$ & $2,446,048$ & $2,446,048$ & $2,446,048$ & $2,446,048$ & $2,446,048$ & $2,446,048$ \\
\hline YEAR FE & Y & $\mathrm{Y}$ & Y & $\mathrm{Y}$ & $\mathrm{Y}$ & $\mathrm{Y}$ & $\mathrm{Y}$ & $\mathrm{Y}$ & Y \\
\hline FIRM FE & $\mathrm{Y}$ & $\mathrm{Y}$ & Y & $\mathrm{Y}$ & $\mathrm{Y}$ & $\mathrm{Y}$ & $\mathrm{Y}$ & $\mathrm{Y}$ & $\mathrm{Y}$ \\
\hline FIRM SIZE CONTROLS & $\mathrm{Y}$ & Y & $\mathrm{Y}$ & Y & $\mathrm{Y}$ & $\mathrm{Y}$ & $\mathrm{Y}$ & Y & Y \\
\hline INDUSTRY CONTROLS & $\mathrm{Y}$ & $\mathrm{Y}$ & $\mathrm{Y}$ & $\mathrm{Y}$ & $\mathrm{Y}$ & $\mathrm{Y}$ & $\mathrm{Y}$ & $\mathrm{Y}$ & Y \\
\hline
\end{tabular}

Robust standard errors clustered at country-(34 TiVA) industry level, ${ }^{* * *} p<0.01,{ }^{* *} p<0.05,{ }^{*} p<0.1$

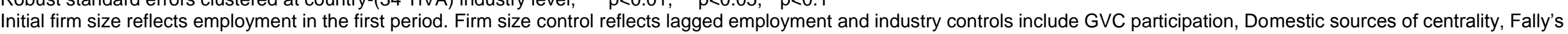

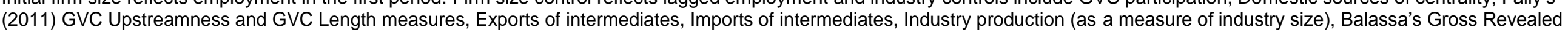
Comparative Advantage, and Koopman et al.'s (2014) Value-Added Revealed Comparative Advantage. 
Figure 2. Annual Increase in MFP for Frontier and Non-Frontier Firms for mean growth in Productivity of Buyers / Suppliers

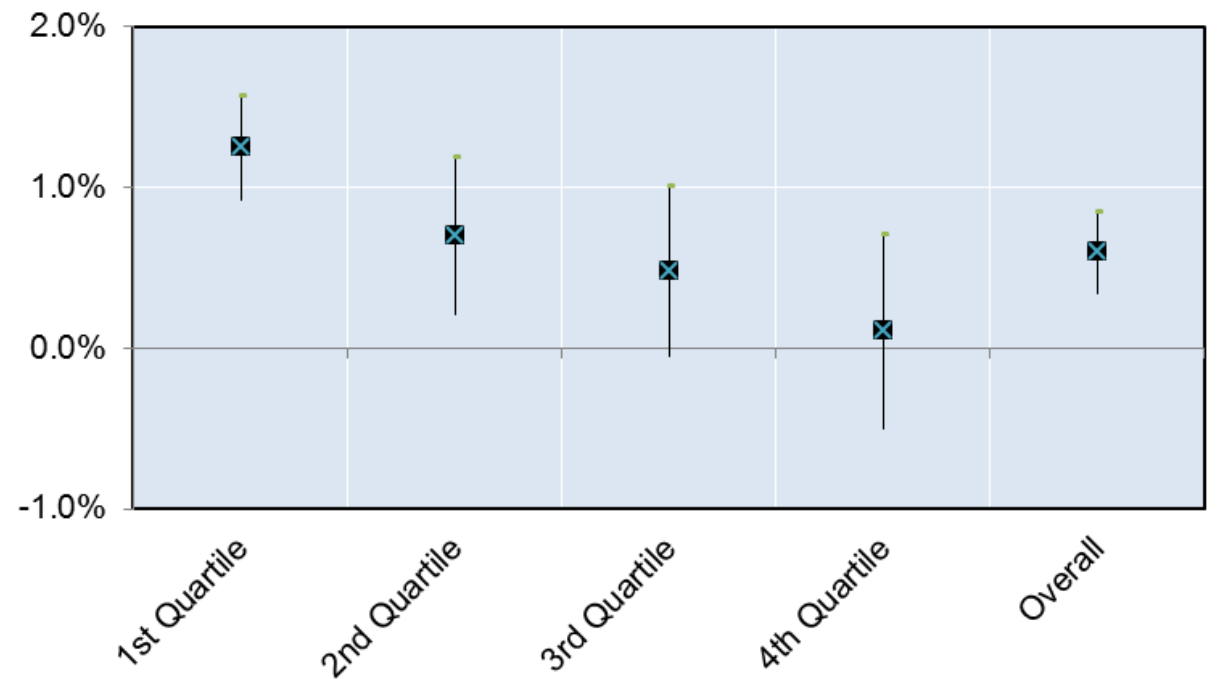

Note: Mean estimated (annual) correlations are reflected as points, with $95 \%$ confidence interval bars. Shown for firms of different quartiles of initial MFP, with $1^{\text {st }}$ quartile representing the less productive initially to those most productive in the $4^{\text {th }}$ quartile. Based on estimates from regressions including industry controls.

Figure 3. Annual Increase in MFP for Larger and Smaller Firms for mean growth in Productivity of Buyers / Suppliers

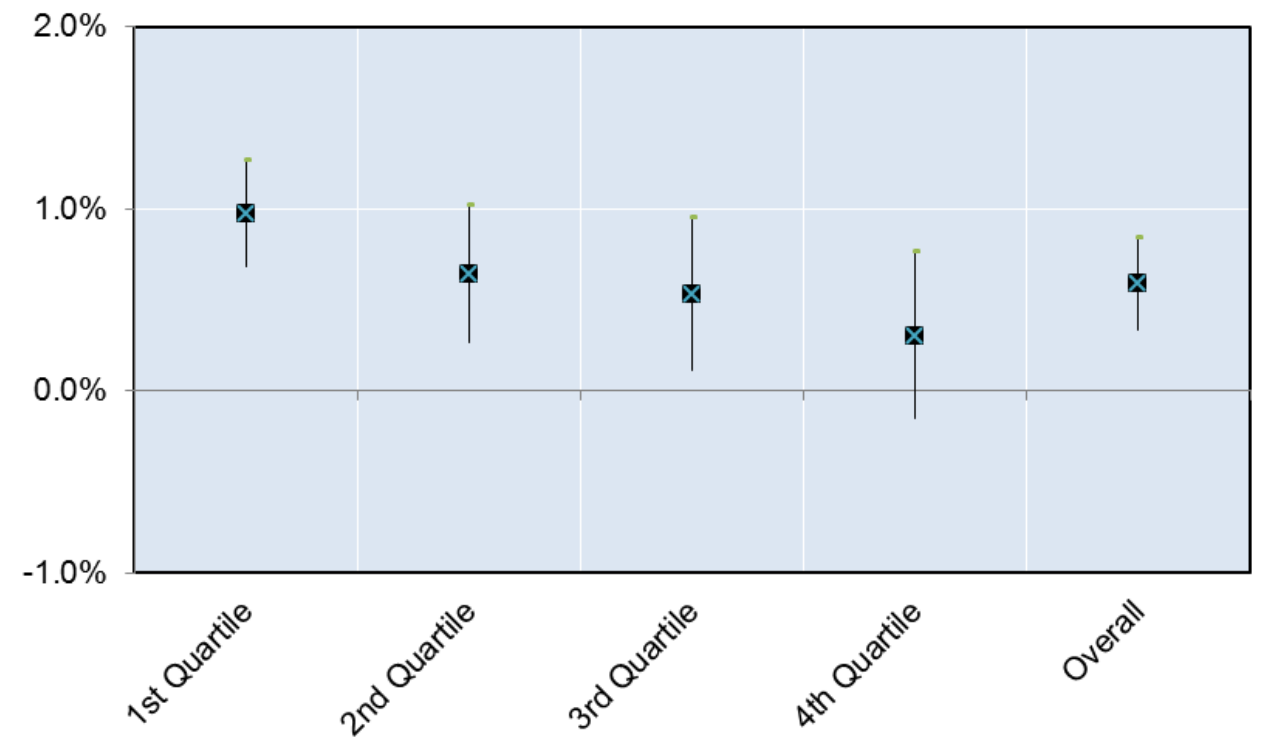

Note: Mean estimated (annual) correlations are reflected as points, with 95\% confidence interval bars. Shown for firms of different quartiles of initial employment, with $1^{\text {st }}$ quartile representing those smaller initially (sales less than 3 million PPP\$) to the largest in the $4^{\text {th }}$ quartile (above 23 million PPP\$). Based on estimates from regressions including industry controls.

\section{Heterogeneity - Which Countries?}

47. This section examines potential heterogeneity by country, focusing on changes within Factory Europe (which is relatively well covered by Orbis) and differences by 
country size. In terms of changes within Europe, we consider the group of post-2004 EU accession countries and other European countries separately ${ }^{15}$. Descriptive results presented in Criscuolo and Timmis (2018) showed that the European value chains have undergone large structural changes, with increasing centrality of post-2004 EU accession countries. Earlier results in this paper revealed that although centrality does not seem to impact firm productivity on average, it can play a role in the catch up of non-frontier firms. At the start of our period, many post-2004 EU economies had productivity levels below the European average. Therefore, the increasing integration of these economies into GVCs may affect firm performance differently to those European economies that were already relatively central and with relatively high productivity at the start of the period.

48. In terms of centrality, we find evidence of heterogeneity across countries in our sample; centrality appears to matter for the productivity of the "average" firm in post2004 EU accession countries but not for the rest of Factory Europe. Firms in post-2004 EU accession countries show faster productivity increases in sectors that become increasingly central to global value chains (see column 1, Table 4). Increasing centrality seems to be particularly important in terms of becoming a key buyer (through backward linkages as a user of foreign inputs), but also as a key supplier (columns 2 and 3 respectively). Many Eastern European countries have become offshore destinations of multinationals, with some industries such as automotive salient examples of this. Offshored production, particularly in assembly-type activities, is strongly driven by the ability to utilise a wide range of imported intermediates (see discussion in De Backer and Miroudot, 2013). Therefore, it is perhaps not surprising that becoming increasing central in terms of backward linkages that appears to relate to firm productivity gains. However, one caveat to note is that our firm-level data coverage of post-2004 EU economies is relatively limited and so the conclusions reached here may be stronger or weaker in more comprehensive data. In contrast, only forwards centrality appears to influence firm productivity in other European countries, with backwards and total centrality consistent with the baseline (columns 4 to 6).

49. In terms of the (centrality weighted) average productivity of buyers / sellers we also find evidence of heterogeneity; the composition of buyers / suppliers appears to matter for the "average" firm in the rest of Factory Europe but less so for post-2004 EU members. In post-2004 EU members there is weak evidence that the average productivity of foreign buyers (via forward linkages), but not suppliers, influences firm productivity (columns 2 to 3). In contrast, for the rest of Factory Europe, firms on average have faster productivity increases in industries connected to faster growing buyers (through forwards linkages, column 5), and also faster growing suppliers (column 6). It therefore appears as though the composition of buyer and supplier networks matters more for the rest of Factory Europe, but less so for post-2004 EU members.

50. Considering frontier and non-frontier firms, we see broadly consistent evidence for both post-2004 EU members and other European countries, with the composition of buyers / suppliers most strongly correlated with the productivity of non-frontier firms (see Annex A Table A.1). Similarly, for the post-2004 EU countries we find that (forwards, backwards or total) centrality matters for the productivity of non-frontier firms, but this

15 Unfortunately, it is not possible to perform a similar exercise considering Factory Asia separately, because of limited ORBIS coverage of Asian economies. 
decays with proximity to the frontier. In contrast, for the rest of Factor Europe, we find no correlation between productivity and centrality for any firm type.

51. Our second measure of country heterogeneity examines differences by country size (measured by population) ${ }^{16}$. We define smaller countries as those below the median population in our sample (fewer than 16.8 million people) and larger countries with those above the median. It is not clear a priori whether any productivity effects should be stronger in smaller or larger economies. On the one hand, smaller economies are often more integrated with foreign economies due to the limited scale of their domestic markets. The greater exposure to foreign sectors, combined with potentially shorter domestic supply chains, may increase the propensity for productivity to diffuse domestically. On the other hand, smaller markets are often more exposed to foreign shocks, which may be amplified by becoming a key hub, and so constrain any productivity effects of centrality. In addition, being a key hub is correlated with size (as shown in Criscuolo and Timmis, 2018), suggesting that any centrality may be reinforced by size of countries.

52. We find evidence of heterogeneity across country size: centrality is linked with the productivity of firms in smaller countries but being connected to more productive suppliers or customers matters much less, whereas, for the larger countries we find the reverse (see Table 5). Firstly, becoming a key hub is associated with increases in the productivity of firms in smaller countries (column 1), and the increase in productivity is evident through both forwards and backwards centrality (columns 2 and 3). In contrast, for larger countries we find little evidence of centrality being correlated with firm productivity, mirroring the baseline (column 4 to 6). Secondly, the productivity of buyers (via forwards linkages), but not suppliers, is related to the productivity of firms in larger countries, mirroring the baseline results (columns 5 and 6 respectively). We find little evidence that the composition of buyers or suppliers impacts the productivity of firms in smaller countries (columns 1 to 3 ).

53. Considering frontier and non-frontier firms, we see broadly consistent evidence for both large and small countries, with the composition of buyers / suppliers most strongly correlated with the productivity of non-frontier firms and weakening with proximity to the frontier (see Annex A Table A.2). However, we see less evidence of a distinction between frontier and non-frontier firms in terms of centrality, surprisingly, with no correlations evident for smaller countries. This may be due to the limited sample of firms in our data from these economies, restricting our ability to disentangle the heterogeneity by both country and firm type. ${ }^{17}$

\footnotetext{
${ }^{16}$ One alternative avenue is to group by income, for example splitting OECD and non-OECD countries or based on World Bank income classifications of countries. However, as noted earlier, the sample is overwhelmingly comprised of high-income OECD economies, representing more than $90 \%$ of firms in the analysis, limiting the reliability of any conclusions drawn from such a restricted sample.
}

17 In Table A.2, the size of the standard errors suggest that these centrality estimates are imprecisely estimated (compared to the baseline), rather than estimated coefficients closer to zero. 
Table 4. Heterogeneity by country: Post-2004 EU Accession vs Other Factory Europe

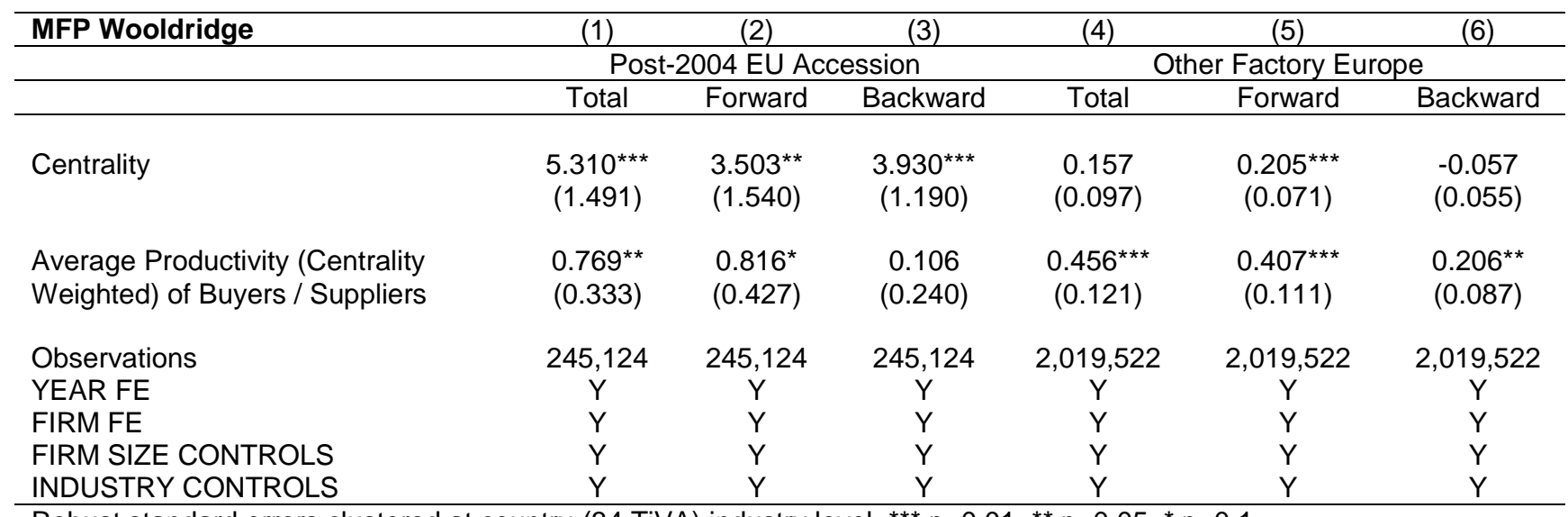

Robust standard errors clustered at country-(34 TiVA) industry level, ${ }^{* \star}{ }^{*} p<0.01,{ }^{* *} p<0.05,{ }^{*} p<0.1$

Firm size control reflects lagged employment. Industry controls include GVC participation, Domestic sources of centrality, Fally's (2011) GVC Upstreamness and GVC Length measures, Exports of intermediates, Imports of intermediates, Industry production (as a measure of industry size), Balassa's Gross Revealed Comparative Advantage, and Koopman et al.'s (2014) Value-Added Revealed Comparative Advantage. The post-2004 EU accession countries in our sample are Bulgaria, Estonia, Hungary, Latvia, Poland, Romania and Slovenia. Other Factory Europe comprise Austria, Belgium, Germany, Denmark, Finland, France, Ireland, Italy, Luxembourg, the Netherlands, Portugal, Sweden, Spain, Turkey and the United Kingdom.

Table 5. Heterogeneity by country: Smaller vs Larger Countries

\begin{tabular}{|c|c|c|c|c|c|c|}
\hline MFP Wooldridge & (1) & (2) & (3) & (4) & (5) & (6) \\
\hline & \multicolumn{3}{|c|}{ Smaller Countries } & \multicolumn{3}{|c|}{ Larger Countries } \\
\hline & Total & Forward & Backward & Total & Forward & Backward \\
\hline Centrality & $\begin{array}{l}0.996^{* * *} \\
(0.269)\end{array}$ & $\begin{array}{c}0.698^{* * *} \\
(0.198)\end{array}$ & $\begin{array}{l}0.340^{* *} \\
(0.143)\end{array}$ & $\begin{array}{c}0.170 \\
(0.154)\end{array}$ & $\begin{array}{l}-0.023 \\
(0.097)\end{array}$ & $\begin{array}{l}0.163^{*} \\
(0.097)\end{array}$ \\
\hline $\begin{array}{l}\text { Average Productivity (Centrality } \\
\text { Weighted) of Buyers / Suppliers }\end{array}$ & $\begin{array}{c}0.163 \\
(0.154)\end{array}$ & $\begin{array}{l}0.228^{*} \\
(0.135)\end{array}$ & $\begin{array}{l}-0.009 \\
(0.113)\end{array}$ & $\begin{array}{c}0.664^{\star * \star} \\
(0.187)\end{array}$ & $\begin{array}{l}1.036^{\star * *} \\
(0.280)\end{array}$ & $\begin{array}{c}0.029 \\
(0.245)\end{array}$ \\
\hline $\begin{array}{l}\text { Observations } \\
\text { YEAR FE } \\
\text { FIRM FE } \\
\text { FIRM SIZE CONTROLS } \\
\text { INDUSTRY CONTROLS }\end{array}$ & $\begin{array}{c}450,779 \\
Y \\
Y \\
Y \\
Y\end{array}$ & $\begin{array}{c}450,779 \\
Y \\
Y \\
Y \\
Y\end{array}$ & $\begin{array}{c}450,779 \\
Y \\
Y \\
Y \\
Y\end{array}$ & $\begin{array}{c}1,995,269 \\
Y \\
Y \\
Y \\
Y\end{array}$ & $\begin{array}{c}1,995,269 \\
Y \\
Y \\
Y \\
Y\end{array}$ & $\begin{array}{c}1,995,269 \\
Y \\
Y \\
Y \\
Y\end{array}$ \\
\hline
\end{tabular}

Robust standard errors clustered at country-(34 TiVA) industry level, ${ }^{* * *} p<0.01,{ }^{* \star} p<0.05,{ }^{*} p<0.1$

Firm size control reflects lagged employment. Industry controls include GVC participation, Domestic sources of centrality, Fally's (2011) GVC Upstreamness and GVC Length measures, Exports of intermediates, Imports of intermediates, Industry production (as a measure of industry size), Balassa's Gross Revealed Comparative Advantage, and Koopman et al.'s (2014) Value-Added Revealed Comparative Advantage. Smaller countries are though below the median country's population at the start of the period (16.8million), and include Austria, Belgium, Bulgaria, Denmark, Estonia, Finland, Hungary, Ireland, Luxembourg, Latvia, the Netherlands, Portugal, Slovenia and Sweden. Larger countries are Australia, China, France, Germany, India, Italy, Japan, Korea, Poland, Romania, Spain, Turkey, UK and the USA.

\section{Heterogeneity - Which Sectors?}

54. There have been profound changes in the structure of GVCs, with notable contrasts across manufacturing and services sectors (Criscuolo and Timmis, 2018). In particular, some manufacturing value chains had shifted from traditional centres of production to E. Europe and Asia, whereas many services have become more important for value chains (almost) universally. This section examines whether earlier productivity 
results show similar distinctions across these sectors, by considering firms in manufacturing and services sectors separately.

55. Looking at the performance of all firms in either services or manufacturing industries we find little evidence of differential correlations between the two sectors. Table 6 repeats the baseline specification separately for services sector and manufacturing firms, with the results reported in columns 1 to 3 and 4 to 6 respectively. Firstly, as in the baseline we find no evidence of a role of centrality in the productivity of the average manufacturing firm (columns 4 to 6). However, there is limited evidence that changes in total centrality is correlated with changes in productivity of services firms, but this does not persist when disentangling forwards or backwards (columns 1, 2 and 3 respectively). Secondly, considering the productivity of foreign buyers and suppliers, the results also mirror the baseline. Firms have faster productivity changes when supplying faster growing foreign buyers (via forwards linkages) in either the services or manufacturing sector, but we find no correlation with backwards linkages.

56. Contrasting frontier and non-frontier firms, we see more evidence of heterogeneity across manufacturing and services sector (see Annex A - Table A.3). Firstly, for services we find that becoming a key customer (backwards centrality) or key supplier (forwards centrality) correlates with the productivity of non-frontier firms and this decays with proximity to the frontier. However, we find more limited evidence that centrality is correlated with non-frontier productivity in manufacturing. Secondly, the previous section suggested that non-frontier firms have faster productivity increases when connected to faster growing foreign buyers or suppliers. We find consistent results here for non-frontier firms from both forwards and backwards linkages in both manufacturing and services, with again the correlation weakening with proximity to the frontier.

Table 6. Heterogeneity by industry: Services vs Manufacturing

\begin{tabular}{|c|c|c|c|c|c|c|}
\hline MFP Wooldridge & (1) & (2) & (3) & (4) & (5) & (6) \\
\hline & \multicolumn{3}{|c|}{ Services } & \multicolumn{3}{|c|}{ Manufacturing } \\
\hline & Total & Forward & Backward & Total & Forward & Backward \\
\hline Centrality & $\begin{array}{l}0.444^{* *} \\
(0.220)\end{array}$ & $\begin{array}{c}0.179 \\
(0.113)\end{array}$ & $\begin{array}{c}0.131 \\
(0.116)\end{array}$ & $\begin{array}{l}-0.146 \\
(0.240)\end{array}$ & $\begin{array}{l}-0.575 \\
(0.370)\end{array}$ & $\begin{array}{c}0.127 \\
(0.129)\end{array}$ \\
\hline $\begin{array}{l}\text { Average Productivity (Centrality } \\
\text { Weighted) of Buyers / Suppliers }\end{array}$ & $\begin{array}{c}0.619^{* * *} \\
(0.204)\end{array}$ & $\begin{array}{l}1.030^{* *} \\
(0.433)\end{array}$ & $\begin{array}{l}-0.059 \\
(0.252)\end{array}$ & $\begin{array}{l}0.493^{* * *} \\
(0.188)\end{array}$ & $\begin{array}{c}0.633^{\star * \star} \\
(0.169)\end{array}$ & $\begin{array}{c}0.158 \\
(0.168)\end{array}$ \\
\hline Observations & $1,331,042$ & $1,331,042$ & $1,331,042$ & $1,114,983$ & $1,114,983$ & $1,114,983$ \\
\hline YEAR FE & Y & Y & Y & $Y^{\prime}$ & Y & Y \\
\hline FIRM FE & Y & Y & Y & Y & Y & Y \\
\hline FIRM SIZE CONTROLS & Y & Y & Y & Y & Y & Y \\
\hline INDUSTRY CONTROLS & Y & Y & Y & Y & Y & Y \\
\hline
\end{tabular}

Robust standard errors clustered at country-(34 TiVA) industry level, ${ }^{\star \star *} p<0.01,{ }^{\star *} p<0.05,{ }^{*} p<0.1$

Firm size control reflects lagged employment. Industry controls include GVC participation, Domestic sources of centrality, Fally's (2011) GVC Upstreamness and GVC Length measures, Exports of intermediates, Imports of intermediates, Industry production (as a measure of industry size), Balassa's Gross Revealed Comparative Advantage, and Koopman et al.'s (2014) Value-Added Revealed Comparative Advantage. 


\section{Heterogeneity - Indirect vs Direct Foreign Linkages?}

57. The earlier results showing stronger correlations with the productivity of smaller and less productive firms suggest that domestic spillovers may be at least as important as the direct impacts of being engaged with GVCs. To participate directly in GVCs requires scale and there is a large literature demonstrating the productivity gains to these direct participants, through exporting, importing or FDI (e.g. Amiti and Konings, 2007; Goldberg et al., 2010; Javorcik, 2004). However, our results suggest they productivity impacts can be stronger for less productive and smaller firms, which are unlikely to directly engage in GVCs. On the one hand, this is perhaps unsurprising, since these firms have a larger potential gains from foreign spillovers. But on the other hand, this also suggests the importance of a different channel: indirect linkages to foreign sectors. These smaller, less productive firms could participate indirectly as a supplier of an exporter for instance. Whilst our data does not allow measurement of this at a firm-level, we examine this hypothesis at a sectoral level by decomposing our centrality measure.

58. We separate our foreign centrality measure into centrality due to direct foreign linkages - that start and remain abroad - and due to indirect foreign linkages - that pass through domestic sectors on their way abroad. Our centrality variables thus far explain how interconnected sectors are with foreign sectors, but this encompasses both direct foreign linkages (e.g. exporters / importers) and indirect foreign linkages (e.g. domestic firms supplying exporters, or domestic firms using the intermediates produced by importers). Empirically, we add to our baseline regressions the centrality that is due to direct foreign linkages and also the average productivity of these directly connected foreign sectors. Note, however that this approach is clearly a rough measure of domestic spillovers from GVCs, since it only measures the extent they are reflected in input linkages, which is a subset of all possible spillover channels: ownership linkages, labour mobility, geographic proximity etc.

59. We find some evidence that indirect foreign linkages matter more than direct foreign linkages for firm productivity. Firstly, we find no robust evidence of a role of centrality (due to direct or indirect linkages) in the productivity of the average manufacturing firm (the first two rows of Table 7). Secondly, as in the baseline, firms have faster productivity increases when supplying faster growing foreign buyers (via forwards linkages), and no correlation with backwards linkages (see the third row). However, firm productivity increases are stronger in sectors that have stronger indirect linkages to highly productive foreign sectors (e.g. as domestic suppliers of exporters) compared to those sectors with stronger direct linkages (e.g. as exporters) (see the fourth row). That we find indirect foreign linkages seem to matter more and particularly through the forwards linkage channel, is consistent with a narrative where foreign firms share knowledge with domestic suppliers, with spillovers down the supply chain, consistent with the aforementioned literature on FDI spillovers (e.g. Godart and Görg, 2013; Havránek and Iršova, 2011). 
Table 7. Heterogeneity by Direct or Indirect Foreign Linkages

\begin{tabular}{|c|c|c|c|c|c|c|}
\hline \multirow{2}{*}{ MFP Wooldridge } & (1) & \multirow[t]{2}{*}{ (2) } & \multirow{2}{*}{\multicolumn{2}{|c|}{${ }^{(3)}$ Forward ${ }^{(4)}$}} & \multicolumn{2}{|l|}{ (5) } \\
\hline & & & & & \multicolumn{2}{|c|}{ Backward } \\
\hline \multirow[t]{2}{*}{ Centrality } & -0.121 & $0.312 *$ & -0.100 & 0.057 & 0.008 & $0.349 *$ \\
\hline & $(0.153)$ & $(0.187)$ & (0.119) & $(0.106)$ & $(0.113)$ & $(0.192)$ \\
\hline \multirow[t]{2}{*}{ Direct Foreign Centrality } & 0.163 & -0.220 & 0.143 & 0.059 & -0.015 & -0.530 \\
\hline & (0.304) & $(0.287)$ & $(0.200)$ & $(0.176)$ & (0.249) & $(0.377)$ \\
\hline Average Productivity (Centrality & $1.411 * * *$ & $1.461 * * *$ & $1.032 * * *$ & $1.236 * * *$ & 0.302 & 0.099 \\
\hline Weighted) of Buyers / Suppliers & $(0.461)$ & $(0.382)$ & $(0.350)$ & $(0.288)$ & $(0.538)$ & $(0.444)$ \\
\hline Average Productivity (Centrality & $-0.539 * *$ & $-0.645^{* *}$ & -0.132 & $-0.297^{*}$ & -0.086 & -0.011 \\
\hline Weighted via Direct Foreign & $(0.257)$ & $(0.263)$ & $(0.161)$ & $(0.155)$ & $(0.333)$ & $(0.258)$ \\
\hline \multicolumn{7}{|l|}{ Linkages) of Buyers / Suppliers } \\
\hline Observations & $2,446,048$ & $2,446,048$ & $2,446,048$ & $2,446,048$ & $2,446,048$ & $2,446,048$ \\
\hline YEAR FE & Y & Y & $\mathrm{Y}$ & Y & Y & $\mathrm{Y}$ \\
\hline FIRM FE & Y & Y & Y & Y & Y & Y \\
\hline FIRM SIZE CONTROLS & Y & Y & Y & Y & Y & Y \\
\hline INDUSTRY CONTROLS & $\mathrm{N}$ & $\mathrm{Y}$ & $\mathrm{N}$ & $\mathrm{Y}$ & $\mathrm{N}$ & $\mathrm{Y}$ \\
\hline \multicolumn{7}{|c|}{$\begin{array}{l}\text { Robust standard errors clustered at country-(34 TiVA) industry level, }{ }^{* \star *} p<0.01,{ }^{* *} p<0.05,{ }^{*} p<0.1 \\
\text { Firm size control reflects lagged employment. Industry controls include GVC participation, Domestic sources of } \\
\text { centrality, Fally's (2011) GVC Upstreamness and GVC Length measures, Exports of intermediates, Imports of } \\
\text { intermediates, Industry production (as a measure of industry size), Balassa's Gross Revealed Comparative Advantage, } \\
\text { and Koopman et al.'s (2014) Value-Added Revealed Comparative Advantage. } \\
\text { Direct Foreign Centrality reflects centrality due to input flows that start and remain abroad (e.g. via expoters or } \\
\text { importers) and Average Productivity (Centrality Weighted via Direct Foreign Linkages) refers to the average productivity } \\
\text { of foreign sectors connected by input flows that start and remain abroad, Centrality reflects total centrality due to input } \\
\text { flows that start and remain abroad and also pass through domestic sectors on their way abroad, }\end{array}$} \\
\hline
\end{tabular}

\section{Robustness Analyses}

60. In this section we perform a series of robustness checks to our main empirical results. These include alternative measures of outcomes and our key explanatory variables. For instance, using mark-up adjusted MFP as an alternative measure of firm performance, employing an alternative variant of our main centrality measure and comparing our results against GVC participation metrics. In addition, we restrict the sample to exclude multinationals and their affiliates from the analysis and focus on countries with better Orbis coverage. Finally, out of a concern our variables of interest may not be exogenously determined, we undertake instrumental variable estimation.

\section{Robustness - Mark-up Adjusted MFP}

61. One concern might be that our approach thus far has been conflating the impact of GVCs on competition and prices/mark-ups and the impact on (quantity-based) productivity. Imports can affect competition in domestic markets and hence firm markups (De Loecker and Van Biesebroeck, 2016). The previous analysis estimated revenue based MFP, due to the absence of data on firm prices, which is a common constraint in the literature. Revenue-based MFP reflects both changes in quantify-based MFP as well as changes in mark-ups. Therefore, it may be that increasing centrality may both lead to knowledge diffusion that increases quantity-based MFP, but is offset by increased foreign competition, and hence lower mark-ups. In this section we repeat the baseline estimation 
controlling for unobservable firm markups using the method of De Loecker and Warzynski (2012) to report mark-up adjusted firm MFP.

62. We find the baseline results are largely unchanged when using mark-up adjusted MFP as a measure of firm productivity. We find little evidence of faster firm productivity increases in sectors that become more central, when using mark-up adjusted measures of firm productivity (see Table 8). Sectors that become more central in terms of total linkages exhibit faster firm productivity increases when including industry controls (see column 2), but this is not robust to estimation without these controls, nor decomposing the forward and backwards centrality (columns 1 and 3 to 6 respectively). The results for the productivity of buyers and suppliers are unchanged from the baseline measure of MFP. In particular, firms have faster productivity rises in industries that supply more productive foreign customers (forwards linkages, columns 3 and 4).

Table 8. Robustness: Mark-up Corrected MFP

\begin{tabular}{|c|c|c|c|c|c|c|}
\hline \multirow[t]{2}{*}{ Mark-up Corrected MFP } & \multirow{2}{*}{\multicolumn{2}{|c|}{ Total }} & \multirow{2}{*}{\multicolumn{2}{|c|}{$\begin{array}{l}\text { (3) Forward } \\
\text { F) }\end{array}$}} & \multirow{2}{*}{\multicolumn{2}{|c|}{$\begin{array}{l}\text { (5) } \\
\text { Backward } \\
\end{array}$}} \\
\hline & & & & & & \\
\hline Centrality & $\begin{array}{l}-0.058 \\
(0.069)\end{array}$ & $\begin{array}{l}0.315^{\star *} \\
(0.158)\end{array}$ & $\begin{array}{l}-0.047 \\
(0.058)\end{array}$ & $\begin{array}{c}0.130 \\
(0.093)\end{array}$ & $\begin{array}{l}-0.019 \\
(0.063)\end{array}$ & $\begin{array}{c}0.133 \\
(0.093)\end{array}$ \\
\hline $\begin{array}{l}\text { Average Productivity (Centrality } \\
\text { Weighted) of Buyers / Suppliers }\end{array}$ & $\begin{array}{l}0.642^{* * *} \\
(0.190)\end{array}$ & $\begin{array}{l}0.589^{* * *} \\
(0.145)\end{array}$ & $\begin{array}{l}0.823^{* * *} \\
(0.236)\end{array}$ & $\begin{array}{l}0.837^{* * *} \\
(0.213)\end{array}$ & $\begin{array}{c}0.133 \\
(0.171)\end{array}$ & $\begin{array}{c}0.059 \\
(0.181)\end{array}$ \\
\hline Observations & $2,080,154$ & $2,080,154$ & $2,080,154$ & $2,080,154$ & $2,080,154$ & $2,080,154$ \\
\hline YEAR FE & $\mathrm{Y}$ & $\mathrm{Y}$ & $\mathrm{Y}$ & $\mathrm{Y}$ & Y & $\mathrm{Y}$ \\
\hline FIRM FE & $Y$ & $\mathrm{Y}$ & Y & Y & Y & Y \\
\hline FIRM SIZE CONTROLS & $Y$ & Y & Y & Y & Y & $\mathrm{Y}$ \\
\hline INDUSTRY CONTROLS & $\mathrm{N}$ & Y & $\mathrm{N}$ & Y & $\mathrm{N}$ & Y \\
\hline \multicolumn{7}{|c|}{$\begin{array}{l}\text { Robust standard errors clustered at country-(34 TiVA) industry level, }{ }^{* \star} \mathrm{p}<0.01,{ }^{* *} \mathrm{p}<0.05,{ }^{*} \mathrm{p}<0.1 \\
\text { Firm size control reflects lagged employment. Industry controls include GVC participation, Domestic sources of } \\
\text { centrality, Fally's (2011) GVC Upstreamness and GVC Length measures, Exports of intermediates, Imports of } \\
\text { intermediates, Industry production (as a measure of industry size), Balassa's Gross Revealed Comparative Advantage, } \\
\text { and Koopman et al.'s (2014) Value-Added Revealed Comparative Advantage. }\end{array}$} \\
\hline
\end{tabular}

\section{Robustness - Centrality with Industry-Specific Parameters}

63. In analyses thus far we have employed the centrality constructed by Criscuolo and Timmis (2018), which uses constant parameters across countries and industries, a standard approach in the network literature. In the centrality metric, direct connections are given more importance than higher-order indirect connections. One of the key parameters underlying this metric governs how much additional importance to give to direct connections, compared to higher order indirect connections (see discussion within Criscuolo and Timmis, 2018). Some authors have instead calculated centrality using a parameter that varies by country and industry (such as Imbs and Pauwels, 2016; or Acemoglu et al, 2015) ${ }^{18}$. We examine robustness of our results using this variant of our main centrality metric.

${ }^{18}$ Specifically, the parameter $\lambda$ which determines the rate of decay of higher order network linkages is given by each country-industry's share of intermediates in production (rather than the average across all country-industries in the baseline specification), and $\eta$ is defined as $1-\lambda$ as in the baseline. 
64. Our baseline results are largely robust to employing this variant of our main centrality measure (see Table 9). ${ }^{19}$ We find weak evidence of faster firm productivity increases in sectors that become more central, in terms of total or backwards linkages, but this is only present when including industry controls (columns 2 and 6). In the baseline results, productivity growth of foreign customers (forwards linkages) but not suppliers was correlated with domestic firm productivity changes. Here, we find that productivity of both foreign customers and suppliers matter (columns 3 to 6). The estimated coefficient is somewhat higher for foreign suppliers (backwards linkages) than foreign customers (forwards linkages). Accordingly, the total impact is estimated to be somewhat higher than the baseline, with a $1 \%$ foreign productivity growth associated with $0.86 \%$ increase of domestic firm productivity here, compared to $0.64 \%$ in the baseline (see Table 2 ). Thus the conclusions from our baseline results are largely robust, and if anything slightly strengthened here.

Table 9. Robustness: Centrality with Industry-Specific Parameters

\begin{tabular}{|c|c|c|c|c|c|c|}
\hline \multirow[t]{2}{*}{ MFP Wooldridge } & \multirow{2}{*}{\multicolumn{2}{|c|}{ Total }} & (3) & (4) & (5) & (6) \\
\hline & & & \multicolumn{2}{|c|}{ Forward } & \multicolumn{2}{|c|}{ Backward } \\
\hline Centrality & $\begin{array}{c}0.013 \\
(0.088)\end{array}$ & $\begin{array}{l}0.294^{* *} \\
(0.149)\end{array}$ & $\begin{array}{l}-0.024 \\
(0.083)\end{array}$ & $\begin{array}{c}0.035 \\
(0.092)\end{array}$ & $\begin{array}{c}0.042 \\
(0.066)\end{array}$ & $\begin{array}{l}0.171^{*} \\
(0.101)\end{array}$ \\
\hline $\begin{array}{l}\text { Average Productivity (Centrality } \\
\text { Weighted) of Buyers / Suppliers }\end{array}$ & $\begin{array}{l}1.061^{\star \star *} \\
(0.285)\end{array}$ & $\begin{array}{l}0.859^{* * *} \\
(0.226)\end{array}$ & $\begin{array}{c}0.617^{\star \star *} \\
(0.230)\end{array}$ & $\begin{array}{l}0.510^{* *} \\
(0.241)\end{array}$ & $\begin{array}{l}1.148^{* * *} \\
(0.381)\end{array}$ & $\begin{array}{l}0.844^{* * *} \\
(0.273)\end{array}$ \\
\hline Observations & $2,446,048$ & $2,446,048$ & $2,446,048$ & $2,446,048$ & $2,446,048$ & $2,446,048$ \\
\hline YEAR FE & Y & Y & Y & Y & Y & Y \\
\hline FIRM FE & Y & Y & Y & Y & Y & Y \\
\hline FIRM SIZE CONTROLS & Y & Y & $\mathrm{Y}$ & Y & Y & Y \\
\hline INDUSTRY CONTROLS & $\mathrm{N}$ & $\mathrm{Y}$ & $\mathrm{N}$ & $\mathrm{Y}$ & $\mathrm{N}$ & Y \\
\hline $\begin{array}{l}\text { Robust standard errors clusterec } \\
\text { Firm size control reflects lagg } \\
\text { centrality, Fally's (2011) GVC } \\
\text { intermediates, Industry producti } \\
\text { and Koopman et al.'s (2014) Val }\end{array}$ & $\begin{array}{l}\text { atry-(34 TiV } \\
\text { loyment. I } \\
\text { amness an } \\
\text { measure o } \\
\text { ed Reveale }\end{array}$ & $\begin{array}{l}\text { A) industry I } \\
\text { dustry con } \\
\text { d GVC Le } \\
\text { industry siz } \\
\text { Comparati }\end{array}$ & $\begin{array}{l}\text { el, }{ }^{\star \star \star} p<0.0 \\
\text { ls include }\end{array}$ & $\begin{array}{l}{ }^{* *} \mathrm{p}<0.05,{ }^{*} \\
\mathrm{vC} \text { particip } \\
\text { Exports of } \\
\text { iross Reveal }\end{array}$ & $\begin{array}{l}<0.1 \\
\text { on, Dome } \\
\text { intermedia } \\
\text { Compara }\end{array}$ & $\begin{array}{l}\text { sources of } \\
\text { Imports of } \\
\text { Advantage, }\end{array}$ \\
\hline
\end{tabular}

\section{Robustness - Labour Productivity}

65. Another possibility is that centrality impacts multi-factor and labour productivity differentially, this may particularly be the case if one is concerned that changes in centrality are simply reflecting the offshoring of production. Labour productivity is simply reflected as value-added per worker, whereas MFP also takes account of the contribution of capital. The growth of GVCs reflects the fragmentation of parts of production processes and the offshoring of tasks to other countries. Firms, particularly in higher-income economies, can offshore labour-intensive tasks to countries with low wages, and retaining the relative capital or intangible-intensive tasks in-house. Offshoring may act as a labour-saving technical change, and therefore one may expect labour productivity to increase by more than MFP (Grossman and Helpman, 2008). In this section we repeat the baseline estimation but with a measure of labour productivity, defined as real value-added per employee.

\footnotetext{
${ }^{19}$ Note, we use this variant both as the centrality measure in Table 8 and for the calculation of average productivity (centrality weighted) of buyers and suppliers.
} 
66. We find the baseline results are largely unchanged when using labour productivity as a measure of firm productivity instead of MFP. We find little evidence of faster firm productivity increases in sectors that become more central (see Table 10). The results for the productivity of buyers and suppliers are very similar to the baseline measure of MFP. In particular, firms have faster productivity rises in industries that supply more productive foreign customers (forwards linkages, columns 3 and 4), and the estimated coefficients are of a broadly similar magnitude to the baseline. Therefore it does not seem as though centrality is only operating as labour-saving technical change, and is not simply reflecting offshoring or other features of the growth of GVCs. To test this more formally, we introduce measures of GVC participation as a robustness check in the next section.

Table 10. Robustness: Labour Productivity

\begin{tabular}{|c|c|c|c|c|c|c|}
\hline \multirow[t]{2}{*}{ Mark-up Corrected MFP } & \multirow{2}{*}{\multicolumn{2}{|c|}{ (2) }} & \multirow{2}{*}{\multicolumn{2}{|c|}{ (4) }} & \multirow{2}{*}{\multicolumn{2}{|c|}{$\begin{array}{l}\text { (5) } \\
\text { Backward }\end{array}$}} \\
\hline & & & & & & \\
\hline Centrality & $\begin{array}{l}-0.031 \\
(0.091)\end{array}$ & $\begin{array}{l}0.269 * \\
(0.160)\end{array}$ & $\begin{array}{c}-0.024 \\
(0.074)\end{array}$ & $\begin{array}{c}0.074 \\
(0.092)\end{array}$ & $\begin{array}{l}-0.010 \\
(0.061)\end{array}$ & $\begin{array}{c}0.145 \\
(0.098)\end{array}$ \\
\hline $\begin{array}{l}\text { Average Productivity (Centrality } \\
\text { Weighted) of Buyers / Suppliers }\end{array}$ & $\begin{array}{c}0.749 * * * \\
(0.223)\end{array}$ & $\begin{array}{c}0.682 * * * \\
(0.151)\end{array}$ & $\begin{array}{c}0.955 * * * \\
(0.285)\end{array}$ & $\begin{array}{c}0.966^{* * *} \\
(0.237)\end{array}$ & $\begin{array}{c}0.193 \\
(0.162)\end{array}$ & $\begin{array}{c}0.098 \\
(0.167)\end{array}$ \\
\hline $\begin{array}{l}\text { Observations } \\
\text { YEAR FE } \\
\text { FIRM FE } \\
\text { FIRM SIZE CONTROLS } \\
\text { INDUSTRY CONTROLS }\end{array}$ & $\begin{array}{c}2,446,048 \\
Y \\
Y \\
Y \\
N\end{array}$ & $\begin{array}{c}2,446,048 \\
Y \\
Y \\
Y \\
Y\end{array}$ & $\begin{array}{c}2,446,048 \\
Y \\
Y \\
Y \\
N\end{array}$ & $\begin{array}{l}2,446,048 \\
Y \\
Y \\
Y \\
Y\end{array}$ & $\begin{array}{c}2,446,048 \\
Y \\
Y \\
Y \\
N\end{array}$ & $\begin{array}{c}2,446,048 \\
Y \\
Y \\
Y \\
Y\end{array}$ \\
\hline \multicolumn{7}{|c|}{$\begin{array}{l}\text { Robust standard errors clustered at country-(34 TiVA) industry level, }{ }^{* * *} p<0.01,{ }^{* *} p<0.05,{ }^{*} p<0.1 \\
\text { Labour Productivity defined as real value added per employee. Firm size control reflects lagged employment. Industry } \\
\text { controls include GVC participation, Domestic sources of centrality, Fally's (2011) GVC Upstreamness and GVC Length } \\
\text { measures, Exports of intermediates, Imports of intermediates, Industry production (as a measure of industry size), } \\
\text { Balassa's Gross Revealed Comparative Advantage, and Koopman et al.'s (2014) Value-Added Revealed Comparative } \\
\text { Advantage. }\end{array}$} \\
\hline
\end{tabular}

\section{Robustness - Comparison vs GVC Participation}

67. One may be concerned that our centrality results are simply reflecting what can already be identified using measures of GVC participation, reflecting the foreign value added content of exports. However, in such a case, the policy conclusions would be somewhat different, reinforcing the well-established importance participating in GVCs, rather than the influence of position within them. GVC participation and centrality are clearly related concepts; an industry cannot be central if it doesn't participate in GVCs. However, the correlation between these two measures is weak (see Criscuolo and Timmis, 2018). Rather it seems participation and position within the GVC network reflect complementary aspects of GVC integration.

68. We do not find evidence that our results are simply capturing GVC participation. In this section we repeat the baseline regression, but add the average productivity of buyer / supplier sources of foreign value-added as an additional explanatory variable, as well as reporting the correlation with GVC participation (which was already included as a control variable in the baseline specification, but the estimated coefficient was not 
reported $)^{20}$. We find the baseline results are unchanged as a result of the inclusion of these additional GVC participation variables (see Table 11). Firm productivity does not rise faster in industries that become more central or more peripheral. However, productivity growth is faster in industries connected through forward supplier linkages to increasingly productive foreign buyers (columns 3 and 4). We find limited evidence that firms have faster productivity increases in industries that are increasing GVC participation as a supplier (forwards linkages, column 4), but this is only present with the inclusion of industry controls. However, the average productivity of foreign suppliers of value added (columns 5 and 6) or average productivity of foreign customers of domestic value added (columns 3 and 4 ) do not seem to be robustly linked with firm productivity.

Table 11. Robustness: Comparison vs GVC Participation

\begin{tabular}{|c|c|c|c|c|c|c|}
\hline \multirow[t]{2}{*}{ MFP Wooldridge } & \multirow{2}{*}{\multicolumn{2}{|c|}{ Total }} & (3) & \multirow{2}{*}{$\mathrm{rd}^{(4)}$} & (5) & \multirow{2}{*}{$\mathrm{rd}^{(6)}$} \\
\hline & & & For & & Back & \\
\hline Centrality & $\begin{array}{l}-0.067 \\
(0.118)\end{array}$ & $\begin{array}{c}0.298^{*} \\
(0.165)\end{array}$ & $\begin{array}{l}-0.061 \\
(0.077)\end{array}$ & $\begin{array}{c}0.090 \\
(0.096)\end{array}$ & $\begin{array}{c}0.034 \\
(0.071)\end{array}$ & $\begin{array}{c}0.107 \\
(0.076)\end{array}$ \\
\hline Average Productivity (Centrality & $0.412^{\star *}$ & $0.420^{* *}$ & $0.680^{* * *}$ & $0.868^{* * *}$ & 0.140 & 0.045 \\
\hline Weighted) of Buyers / Suppliers & $(0.169)$ & $(0.165)$ & $(0.204)$ & $(0.198)$ & $(0.147)$ & $(0.145)$ \\
\hline GVC Participation & $\begin{array}{c}2.109 \\
(4.362)\end{array}$ & $\begin{array}{c}1.115 \\
(3.823)\end{array}$ & $\begin{array}{c}8.127 \\
(4.970)\end{array}$ & $\begin{array}{c}11.034^{* *} \\
(4.270)\end{array}$ & $\begin{array}{l}-6.261 \\
(8.162)\end{array}$ & $\begin{array}{r}-11.715 \\
(8.253)\end{array}$ \\
\hline Average Productivity (Value Added & $0.691^{*}$ & 0.535 & $0.441^{*}$ & 0.077 & 0.233 & 0.249 \\
\hline Weighted) of Buyers / Suppliers & $(0.385)$ & $(0.380)$ & $(0.259)$ & $(0.223)$ & $(0.306)$ & $(0.240)$ \\
\hline Observations & $2,446,048$ & $2,446,048$ & $2,446,048$ & $2,446,048$ & $2,446,048$ & $2,446,048$ \\
\hline YEAR FE & Y & Y & Y & $Y^{\prime}$ & $Y$ & $Y^{\prime}$ \\
\hline FIRM FE & Y & $Y$ & $Y$ & $\mathrm{Y}$ & $Y$ & $Y$ \\
\hline FIRM SIZE CONTROLS & Y & $\mathrm{Y}$ & $Y$ & Y & $\mathrm{Y}$ & Y \\
\hline INDUSTRY CONTROLS & $\mathrm{N}$ & Y & $\mathrm{N}$ & Y & $\mathrm{N}$ & Y \\
\hline \multicolumn{7}{|c|}{$\begin{array}{l}\text { Robust standard errors clustered at country-(34 TiVA) industry level, }{ }^{* * *} p<0.01,{ }^{* *} p<0.05,{ }^{*} p<0.1 \\
\text { Firm size control reflects lagged employment. Industry controls include Domestic sources of centrality, Fally's (2011) GVC }\end{array}$} \\
\hline
\end{tabular}

\section{Robustness - Multinational Firms}

69. Another concern might be that our results are driven by the presence of multinational firms. Our centrality metric varies at the country-industry level, therefore for each firm we assign a single centrality measure based on the country where the firm is located and primary industry. However, by operating in several countries, the centrality metric is likely to be less informative for multinational firms compared to nonmultinationals. Furthermore, our centrality metric is least likely to be plausibly exogenous for large multinationals, where because of their size, their import and export decisions may be able to influence their industry's centrality. Thus, for multinationals there may be reverse causality: the performance of multinationals may determine centrality, rather than the other way around.

70. To address these concerns we restrict the sample of firms to exclude both multinationals and their affiliates from the analysis. We use the foreign ownership data

\footnotetext{
${ }^{20}$ The average productivity (value added weighted) of buyers / suppliers is calculated identically to the average productivity (centrality weighted) of buyers and suppliers, but instead of uses sources of foreign value-added as weights.
} 
within Orbis to identify firms that are ever identified as multinationals or are ever a foreign affiliate of a multinational. This is a relatively strong restriction, in that we exclude the periods before firms become multinationals or affiliates, as well as after. This leads to a reasonably large reduction in sample size of 417,000 firms, or $17 \%$ of the baseline sample, due to Orbis reflecting mainly medium and larger firms (which are more likely to be multinationals or affiliates). We find that the baseline conclusions are unchanged from excluding these firms (see Table 12). As in the baseline, we do not find that becoming more centrality is correlated with firm productivity increases of the average firm, however there is a strong correlation with the productivity of customers (through forwards linkages), with similar estimated coefficients compared to the baseline.

Table 12. Robustness - Exclude Multinationals and Affiliates

\begin{tabular}{|c|c|c|c|c|c|c|}
\hline \multirow[t]{2}{*}{ MFP Wooldridge } & \multirow{2}{*}{\multicolumn{2}{|c|}{ Total }} & \multirow{2}{*}{\multicolumn{2}{|c|}{ Forward }} & \multirow{2}{*}{\multicolumn{2}{|c|}{$d^{(6)}$}} \\
\hline & & & & & & \\
\hline \multirow[t]{2}{*}{ Centrality } & -0.023 & 0.237 & -0.036 & 0.032 & 0.036 & $0.161^{*}$ \\
\hline & $(0.077)$ & $(0.156)$ & $(0.066)$ & $(0.092)$ & $(0.065)$ & $(0.097)$ \\
\hline Average Productivity (Centrality & $0.714^{* * *}$ & $0.652 * * *$ & $0.905^{* * *}$ & $0.914^{* * *}$ & 0.168 & 0.081 \\
\hline Weighted) of Buyers / Suppliers & $(0.201)$ & $(0.141)$ & $(0.252)$ & $(0.212)$ & $(0.168)$ & $(0.178)$ \\
\hline Observations & $2,028,374$ & $2,028,374$ & $2,028,374$ & $2,028,374$ & $2,028,374$ & $2,028,374$ \\
\hline YEAR FE & $\mathrm{Y}$ & $\mathrm{Y}$ & Y & $\mathrm{Y}$ & Y & $Y$ \\
\hline FIRM FE & $\mathrm{Y}$ & $\mathrm{Y}$ & Y & Y & Y & Y \\
\hline FIRM SIZE CONTROLS & $Y$ & $\mathrm{Y}$ & Y & Y & Y & $\mathrm{Y}$ \\
\hline INDUSTRY CONTROLS & $\mathrm{N}$ & Y & $\mathrm{N}$ & Y & $\mathrm{N}$ & $Y$ \\
\hline \multicolumn{7}{|c|}{$\begin{array}{l}\text { Robust standard errors clustered at country-(34 TiVA) industry level, }{ }^{* * *} p<0.01,{ }^{* *} p<0.05,{ }^{*} p<0.1 \\
\text { Firm size control reflects lagged employment. Industry controls include GVC participation, Domestic sources of centrality, } \\
\text { Fally's (2011) GVC Upstreamness and GVC Length measures, Exports of intermediates, Imports of intermediates, Industry } \\
\text { production (as a measure of industry size), Balassa's Gross Revealed Comparative Advantage, and Koopman et al.'s (2014) } \\
\text { Value-Added Revealed Comparative Advantage. }\end{array}$} \\
\hline
\end{tabular}

\section{Robustness - Coverage}

71. We examine the robustness of the results to focusing on those countries which are better represented within Orbis, with more than 5000 firm-year observations. Although Orbis is the most comprehensive cross-country firm-level data available to us, there are substantial differences in coverage across countries (see Bajgar et al, 2017). One concern might be that our results may be influenced by a minority of outlier firms in poorly covered countries, rather than representing broader trends of medium and large firms in our sample. In the baseline analysis, we considered only countries with more than 500 observations in the matched data, here we restrict the analysis to those countries with more than 5000 observations.

72. Our results are robust to focusing on countries with better Orbis coverage (see Table 13). The coverage restriction leads to 19 countries in the sample (from 28 in the baseline) but only a reduction in the number of firms by 19,000 or less than $1 \%$ of the baseline sample. Although the sample of firms has fallen only slightly, our centrality metrics vary at the country-industry level, therefore the reduction in the sample of countries reduces the variation in our explanatory variables more substantially. Nevertheless, we find that our baseline results are almost unchanged, with no correlation between productivity of firms and centrality, but a strong correlation with the productivity of foreign customers (forwards linkages). 
Table 13. Robustness - Coverage

\begin{tabular}{|c|c|c|c|c|c|c|}
\hline \multirow[t]{2}{*}{ MFP } & \multirow{2}{*}{\multicolumn{2}{|c|}{ Total }} & (3) & \multirow{2}{*}{$\mathrm{rd}^{(4)}$} & \multicolumn{2}{|r|}{ (6) } \\
\hline & & & Forward & & \multicolumn{2}{|c|}{ Backward } \\
\hline \multirow[t]{2}{*}{ Centrality } & -0.037 & 0.243 & -0.036 & 0.045 & 0.005 & 0.149 \\
\hline & $(0.088)$ & $(0.150)$ & $(0.075)$ & $(0.091)$ & $(0.060)$ & $(0.090)$ \\
\hline Average Productivity (Centrality & $0.709 * * *$ & $0.630 * * *$ & $0.885^{* * *}$ & $0.885^{* * *}$ & 0.186 & 0.085 \\
\hline Weighted) of Buyers / Suppliers & $(0.201)$ & $(0.139)$ & $(0.248)$ & $(0.206)$ & $(0.156)$ & $(0.165)$ \\
\hline Observations & $2,427,513$ & $2,427,513$ & $2,427,513$ & $2,427,513$ & $2,427,513$ & $2,427,513$ \\
\hline YEAR FE & $\mathrm{Y}$ & Y & $\mathrm{Y}$ & $\mathrm{Y}$ & $\mathrm{Y}$ & $\mathrm{Y}$ \\
\hline FIRM FE & Y & $\mathrm{Y}$ & Y & Y & Y & Y \\
\hline FIRM SIZE CONTROLS & Y & $\mathrm{Y}$ & Y & $\mathrm{Y}$ & Y & Y \\
\hline INDUSTRY CONTROLS & $\mathrm{N}$ & $\mathrm{Y}$ & $\mathrm{N}$ & $Y$ & $\mathrm{~N}$ & $Y$ \\
\hline
\end{tabular}

Robust standard errors clustered at country-(34 TiVA) industry level, ${ }^{* * *} p<0.01,{ }^{* *} p<0.05,{ }^{*} p<0.1$

Firm size control reflects lagged employment. Industry controls include GVC participation, Domestic sources of centrality, Fally's (2011) GVC Upstreamness and GVC Length measures, Exports of intermediates, Imports of intermediates, Industry production (as a measure of industry size), Balassa's Gross Revealed Comparative Advantage, and Koopman et al.'s (2014) Value-Added Revealed Comparative Advantage. Economies included are Austria, Belgium, Bulgaria, Denmark, Estonia, Finland, France, Germany, Hungary, Ireland, Italy, Korea, the Netherlands, Portugal, Romania, Slovenia, Spain, Sweden and the United Kingdom.

\section{Robustness - Causality and Instrumental Variable Estimation}

73. One concern noted earlier might be that centrality and the choice of buyers and suppliers may not be exogenous and thus the relationship described might be driven by reverse causality or omitted variables bias. However, the earlier results limit some of these concerns. Firstly, the inclusion of firm fixed effects implies that unobserved heterogeneity, i.e. any time-invariant factors that may be correlated with GVCs and firm productivity, is already accounted for, such as geographic factors and distance to foreign markets. Secondly, any productivity effects appear to be predominantly concentrated among smaller and non-frontier firms, with these effects declining with size and proximity to the frontier, and becoming insignificant for the largest, frontier firms. These smaller, non-frontier firms are those least likely to be able to influence changes in positions within the GVC network and are very unlikely to participate in GVCs directly through trade or FDI. However, there may be other industry-level changes that we are not controlling for that may lead to both increases in productivity and changes in centrality. We use instrumental variable estimation to address these concerns.

74. We find our baseline results are broadly unchanged using instrumental variables for centrality and the productivity of foreign buyers and suppliers. As noted earlier, our first instrument predicts changes in centrality with lagged changes (and therefore the sample size reduces somewhat compared to the baseline) ${ }^{21}$. Our second instrument predicts changes in the productivity of foreign buyers and suppliers, using changes in foreign productivity but holding the network of buyers and suppliers fixed. ${ }^{22} \mathrm{We}$ find that

${ }^{21}$ Alternative instruments using natural disasters in third countries or third country EU accession have also been investigated, and although these find similar results to the instrumental variable approach employed here, these had relatively weak predictive power and so have not been reported (first-stage F statistics below 10),

${ }^{22}$ Note we decompose the changes in the average productivity of foreign buyers and suppliers, into two components, within Annex A Table A.4. Firstly, changes in foreign productivity holding the 
both instrumental variables strongly predict our variables of interest (as reflected in Fstatistics and first stage results in the Annex A Table A.5). However, our baseline results are largely unchanged although somewhat more imprecisely estimated, as instrumental variable estimates are less efficient than OLS. We fail to find an effect of centrality on productivity of the average firm, but productivity growth in foreign buyers (through forward linkages) is associated with productivity gains of domestic firms (see Table 14).

Table 14. Robustness: Instrumental Variable Estimation

\begin{tabular}{|c|c|c|c|c|c|c|}
\hline \multirow[t]{2}{*}{ MFP Wooldridge } & (1) & (2) & (3) & (4) & (5) & (6) \\
\hline & \multicolumn{2}{|c|}{ Total } & \multicolumn{2}{|c|}{ Forward } & \multicolumn{2}{|c|}{ Backward } \\
\hline $\begin{array}{l}\text { Secona stage: } \\
\text { Centrality }\end{array}$ & $\begin{array}{l}0.024 \\
(0.130)\end{array}$ & $\begin{array}{l}0.550^{\star} \\
(0.281)\end{array}$ & $\begin{array}{c}0.021 \\
(0.092)\end{array}$ & $\begin{array}{c}0.322 \\
(0.119)\end{array}$ & $\begin{array}{l}-0.014 \\
(0.111)\end{array}$ & $\begin{array}{l}0.106 \\
(0.134)\end{array}$ \\
\hline $\begin{array}{l}\text { Average Productivity (Centrality } \\
\text { Weighted) of Buyers / Suppliers }\end{array}$ & $\begin{array}{c}0.382 \\
(0.269)\end{array}$ & $\begin{array}{l}0.607^{\star *} \\
(0.244)\end{array}$ & $\begin{array}{l}0.555^{\star * *} \\
(0.203)\end{array}$ & $\begin{array}{l}0.695^{\star * *} \\
(0.207)\end{array}$ & $\begin{array}{c}0.074 \\
(0.309)\end{array}$ & $\begin{array}{c}0.331 \\
(0.256)\end{array}$ \\
\hline Kleinbergen-Paap F-statistic & 189.199 & 16.944 & 300.223 & 32.617 & 117.319 & 118.952 \\
\hline Observations & $2,287,415$ & $2,287,415$ & $2,287,415$ & $2,287,415$ & $2,287,415$ & $2,287,415$ \\
\hline YEAR FE & Y & Y & $\mathrm{Y}$ & Y & Y & Y \\
\hline FIRM FE & $\mathrm{Y}$ & Y & Y & Y & Y & Y \\
\hline FIRM SIZE CONTROLS & $\mathrm{Y}$ & Y & Y & Y & $\mathrm{Y}$ & $\mathrm{Y}$ \\
\hline INDUSTRY CONTROLS & $\mathrm{N}$ & Y & $\mathrm{N}$ & Y & $\mathrm{N}$ & Y \\
\hline
\end{tabular}

Robust standard errors clustered at country-(34 TiVA) industry level, ${ }^{* * *} p<0.01,{ }^{* *} p<0.05,{ }^{*} p<0.1$

Firm size control reflects lagged employment. Industry controls include GVC participation, Domestic sources of centrality, Fally's (2011) GVC Upstreamness and GVC Length measures, Exports of intermediates, Imports of intermediates, Industry production (as a measure of industry size), Balassa's Gross Revealed Comparative Advantage, and Koopman et al.'s (2014) Value-Added Revealed Comparative Advantage. First stage regression results are reported in the Annex A.

\section{What is the Role of Policy in Diffusion?}

75. In this section we examine the role of policy in shaping how changes in the structure of GVCs translate into firm productivity gains. We focus on a range of policies that may hamper the ability of firms to upscale and upgrade to leverage new sources of foreign knowledge and technology, as well as those that influence the extent of international trade and FDI linkages. We first examine the role of framework conditions captured by labour market and product market flexibility. Secondly, we introduce a measure of barriers to trade and investment and complexity of customs procedures. Thirdly we consider measures of the contracting environment, as reflected in the protection of intellectual property and a measure of contract enforcement. Finally, we introduce a measure of the barriers to entrepreneurship and the availability of credit, which are likely to be particularly relevant for the upscaling of smaller firms. ${ }^{23}$

network of buyers and suppliers fixed (which is more plausibly exogenous), and secondly, changes in the network of buyers and suppliers, holding their productivity fixed (which is less plausibly exogenous). We find that firm productivity changes are strongly correlated with the first component, but not the second. Thus, firm productivity is mainly associated with foreign productivity growth (holding fixed the network of buyers/suppliers), rather than switching to more productive buyers / suppliers. This reinforces our choice of second instrument.

${ }^{23}$ Alternative policies relating to skills (PIAAC) or service trade restriveness (STRI) unfortunately are not widely available until after our sample period. 
76. In terms of framework policies we focus on two in particular, OECD measures of employment protection legislation (EPL) and product market regulations (PMR). The previous results suggested that centrality and being connected to more productive buyers may play a role in the catch-up of non-frontier or smaller firms. However, evidence suggests that to fully leverage new sources of knowledge or technology, firms require to upscale and make complementary investments in skills, management organisation, processes etc. (see for example Brynjolfsson and Hitt, 2000). Firms are less likely to make such investments if they are sunk, and cannot be recovered in the event they are unsuccessful. Therefore, policies that limit the flexible operation of labour markets are likely to constrain the extent to which smaller firms can yield these potential productivity gains. In addition, limited product market competition is likely to constrain the incentive of firms to expand and move into new product markets, as well as trapping resources in a minority of incumbents.

77. We repeat the baseline specification (considering firms of all types), but include interactions with our two policy variables as additional variables: employment protection legislation and product market regulations ${ }^{24}$. These policy variables reflect the stringency of regulations and hence limitations to competition labour and product markets, and are ranked from a scale of 0 (least restrictive) to 6 (most restrictive). Thus the interaction captures the additional impact of more constraining regulations. These are available from 1998 onwards and so imply some reduction in the sample size compared to earlier baseline results. ${ }^{25}$

78. We find that labour market policy in particular influences the relationship between the productivity growth of buyers or suppliers and firm productivity, with a far stronger relationship in economies with more flexible labour markets. In terms of centrality, we find some evidence of a relationship between backward centrality changes and firm productivity increases in flexible labour markets, and this weakens with labour market rigidity. But mirroring the baseline, there is no relationship with other measures of centrality or any centrality metric and product market flexibility (see Table 15 column 3). However, we find that productivity growth of buyers or suppliers or both is correlated with firm productivity, and this is stronger in economies with more flexible labour markets (columns 1 to 3 ). In contrast, we find that product market competition appears unrelated to how the productivity of buyers or suppliers translates into firm productivity (columns 4 to 6). Note below we examine in more detail salient elements of the PMR indicator: barriers to trade and investment and barriers to entrepreneurship ${ }^{26}$.

79. Earlier analysis suggested that non-frontier firms were most strongly influenced by changes in centrality or productivity of buyers / suppliers, with little evidence for frontier firms. As a final step we consider how policy influences this relationship, focusing on labour market flexibility given the results discussed above. As before, we segment the sample into quartiles based on the initial firm productivity, i.e. the $25 \%$ least productive firms, $25-50^{\text {th }}$ percentiles, $50^{\text {th }}-75^{\text {th }}$ percentiles and above the $75 \%$ most

\footnotetext{
${ }^{24}$ The economy-wide PMR indicator has been used in Table 14, however similar results are obtained if the 2013 Regimpact indicator or the components of the economy-wide PMR indicator.

${ }^{25}$ The results are unchanged using cross-section values for EPL and PMR at the mid-point of our sample (2003) instead of year-specific values.

26 We do not find any role of the state-control subset of the overall PMR indicator, so do not report these results.
} 
productive firms, interacting these quartile dummy variables with our variable of interest: the productivity of buyers / sellers. The role of policy is reflected by including additional triple interaction terms, with our policy measures interacted with these quartile dummy variables and with the productivity of buyers and sellers. Clearly this is a lot of interactions and is working the data quite hard, implying parameters will be estimated more noisily than in previous sections, with larger confidence intervals. We should stress that it is not possible to perform similar analysis for any alternative policy variables, as the estimated coefficients for each quartile of firm for different policy regimes are not estimated with sufficient precision.

80. Labour market policies appear to be particularly relevant for non-frontier firms, their productivity is strongly correlated with the productivity of buyers/suppliers particularly in flexible labour markets, with no such correlation in those most rigid markets. The heterogeneity for firms of different productivity categories (frontier vs nonfrontier) for two different labour market policy regimes are shown in Figure 4. We report the estimated productivity correlation for frontier and non-frontier firms, assuming the mean productivity growth of foreign buyers and sellers (using total linkages - both buyers and sellers). Panel A reflects a more flexible labour market policy, taking the most flexible employment protection legislation in our sample (the US), and Panel B reflects a less flexible labour market, using the least flexible employment protection legislation in our sample (Portugal at the start of the period, 1998). We find in flexible labour markets, productivity growth of buyers/suppliers is correlated with nearly $2 \%$ faster productivity increases per annum of firms furthest from the frontier (quartile 1, panel A). Note this is stronger than the $1 \%$ average estimate across all policy regimes noted in earlier sections. There is a weaker, but positive correlation for firms in the second quartile too. However, for firms closer to the frontier we fail to find any relationship. In contrast, in less flexible labour markets we find no relationship between buyer/supplier productivity and firm productivity neither for frontier or non-frontier firms.

81. Moving from framework policies, we first consider a broad measure of barriers to trade and investment (a subset of the overall PMR indicator) and a measure of customs complexity. Greater exposure to highly productive foreign firms can provide an opportunity for local firms to increase productivity through learning about advanced technologies or good organisational and managerial practices (Saia et al., 2015; Guadalupe et al, 2012). Therefore one would expect that barriers to trade or investment hamper the diffusion of productivity. The first metric reflects barriers to FDI, tariff barriers, barriers to trade facilitation and differential treatment of foreign suppliers and is available from 1998 onwards $^{27}$. The second metric, captures the number of documents needed to export and is taken from the World Bank Doing Business Survey. This variable is only available from the middle of our sample period onwards (in the 2004 survey onwards), and so we take the cross-section of this first reported value and apply it across all time periods.

82. We find that increased customs complexity hampers productivity diffusion from foreign buyers / suppliers, but surprisingly, the PMR measure of barriers to trade and investment appear to be unrelated. As in the baseline specification there is no relationship between centrality and firm productivity on average and this is unchanged by the inclusion of policy variables (see Table 16). However, economies where more documents

27 Again, the results are unchanged using cross-section values of the barriers to trade and investment PMR indicator at the mid-point of our sample (2003) instead of year-specific values. 
are needed to export have weaker productivity diffusion from foreign sectors to domestic firms and those with simplified procedures have stronger diffusion (see Table 16, columns 4 to 6). The role of policy is large, each additional document reduces the correlation with domestic firm productivity by around 13\%, such that there is close to zero correlation for those economies with the least efficient customs procedures in the sample ( 8 documents - China and Turkey). Surprisingly, however, we find no such relationship for the PMR measure of barriers to trade and investment (see columns 1 to 3 of Table 16). Perhaps these barriers would be better reflected using more granular data, for example, product-level tariff information or industry-specific service trade barriers. Unfortunately, such measures, included in the OECD STRI data, are not available until after our sample period (from 2014 onwards).

83. We next include two measures of the contracting environment: the time taken to enforce contracts and a measure of intellectual property rights (IPR). Knowledge spillovers from foreign firms accrue asymmetrically, benefitting firms with sufficient absorptive capacity. Firms and countries are more likely to invest in local innovation and specialise in knowledge-intensive assets, where contracting environments and the protection of intellectual property is strong (Nunn, 2007; Samaniego, 2013). In addition, firms with more knowledge-intensive assets are more likely to trade with local third party suppliers in stronger contracting environment (Antras and Yeaple, 2014). These decisions are likely to impact whether and how foreign technology diffuses to domestic firms.

84. The measure of contract enforcement is taken from the World Bank Doing Business Surveys and measures the time for resolving a commercial dispute through a local first-instance court (in log days). This variable is only available from the middle of our sample period onwards (in the 2004 survey onwards), and so we take the crosssection of this first reported value and apply it across all time periods. The measure of intellectual property rights is taken from the World Economic Forum Global Competitiveness Index through a questionnaire filled in by economic operators in each country. The answers are classified on a scale from 1 to 7 ; the higher the ranking, the better intellectual property protection is perceived to be in that country. Again this is only available from the middle of our sample (from the 2006-7 survey onwards), so we take the cross-section of the first reported value for all periods.

85. We find the level of investor protection, either reflected in contract enforcement or IPR, matters for the diffusion of foreign productivity of buyers / suppliers to domestic firms. In terms of centrality, we find that as in the baseline specification there is no relationship between becoming more central and changes in firm productivity on average and this is unchanged by the inclusion of policy variables (see Table 17). However, we find productivity of buyers or suppliers is more strongly correlated with firm productivity, in economies with better contract enforcement (columns 1 to 3 ). Stronger IPR similarly strengthens the productivity diffusion from suppliers (backwards linkages) or in total, but not from customers (forwards linkages) (columns 4 to 6). Again policy is estimated to have a large influence, particularly in terms of IPR, such that no positive diffusion of productivity is observed in the weakest IPR regimes (in our data, Bulgaria).

86. Finally, we include a broad measure of the barriers to entrepreneurship (a subset of the overall PMR indicator, available from 1998 onwards) and a measure of the availability of credit (taken from the World Economic Forum Global Competitiveness Index, using 2006-7 survey values). Firstly, constraints to entrepreneurship are likely to limit the incentive of firms to expand and move into new product markets, as well as trapping resources in a minority of incumbents. The former indicator reflects the complexity of regulations, administrative burdens on start-ups and regulatory protection 
of incumbents. Secondly, participating in GVCs either directly or as a domestic supplier of an exporter, often requires investment in product and process innovation to meet foreign standards and working capital to finance exports, or provide the trade credit expected by foreign suppliers. In addition, to fully leverage new sources of foreign knowledge or technology, firms require upscaling and complementary investments in skills, management organisation, processes. Such upgrading can require substantial investments and therefore the lack of access to finance can be a major obstacle to firms upgrading their technology and yielding the potential productivity gains. The latter indicator reflects the ease of access to loans, with answers classified on a scale from 1 to 7 ; higher rankings reflect better perceived access to finance.

87. Productivity diffusion from foreign buyers / suppliers to domestic firms is stronger in environments with lower barriers to entrepreneurship and greater access to credit. Again we find the policy environment does not influence the correlation between centrality and firm productivity (see Table 18) but does influence the correlation between firm productivity and the productivity of foreign buyers (via forwards linkages), and particularly suppliers (via backwards linkages). However, we find productivity growth of buyers or suppliers is more strongly correlated with firm productivity increases, in economies with lower barriers to entrepreneurship (columns 1 to 3), and those economies with greater access to credit (columns 4 to 6).

Table 15. What is the Role of Policy in Diffusion? Labour and Product Market Flexibility

\begin{tabular}{|c|c|c|c|c|c|c|}
\hline MFP Wooldridge & (1) & (2) & (3) & (4) & (5) & (6) \\
\hline \multirow[t]{2}{*}{ Policy: } & \multicolumn{3}{|c|}{ Employment Protection Legislation } & \multicolumn{3}{|c|}{ Product Market Regulations } \\
\hline & Total & Forward & Backward & Total & Forward & Backward \\
\hline Centrality & $\begin{array}{l}0.355^{\star \star} \\
(0.146)\end{array}$ & $\begin{array}{l}0.207^{\star} \\
(0.116)\end{array}$ & $\begin{array}{l}0.336^{\star *} \\
(0.137)\end{array}$ & $\begin{array}{c}0.258^{*} \\
(0.134)\end{array}$ & $\begin{array}{c}0.134 \\
(0.117)\end{array}$ & $\begin{array}{c}0.123 \\
(0.080)\end{array}$ \\
\hline Centrality * Policy & $\begin{array}{l}-0.076 \\
(0.052)\end{array}$ & $\begin{array}{l}-0.048 \\
(0.045)\end{array}$ & $\begin{array}{l}-0.101^{\star *} \\
(0.048)\end{array}$ & $\begin{array}{l}-0.027 \\
(0.023)\end{array}$ & $\begin{array}{l}-0.025 \\
(0.021)\end{array}$ & $\begin{array}{l}-0.119 \\
(0.100)\end{array}$ \\
\hline $\begin{array}{l}\text { Average Productivity (Centrality } \\
\text { Weighted) of Buyers / Suppliers }\end{array}$ & $\begin{array}{l}1.648^{\star \star *} \\
(0.362)\end{array}$ & $\begin{array}{l}1.374^{\star \star *} \\
(0.333)\end{array}$ & $\begin{array}{l}1.522^{\star * *} \\
(0.346)\end{array}$ & $\begin{array}{l}0.667^{* * *} \\
(0.215)\end{array}$ & $\begin{array}{l}0.382^{*} \\
(0.197)\end{array}$ & $\begin{array}{l}0.461^{* *} \\
(0.186)\end{array}$ \\
\hline $\begin{array}{l}\text { Average Productivity (Centrality } \\
\text { Weighted) of Buyers / Suppliers * } \\
\text { Policy }\end{array}$ & $\begin{array}{l}-0.449^{\star * *} \\
(0.120)\end{array}$ & $\begin{array}{l}-0.392^{\star * \star} \\
(0.118)\end{array}$ & $\begin{array}{c}-0.474^{\star * \star} \\
(0.117)\end{array}$ & $\begin{array}{l}-0.129 \\
(0.104)\end{array}$ & $\begin{array}{l}-0.045 \\
(0.103)\end{array}$ & $\begin{array}{l}-0.006 \\
(0.024)\end{array}$ \\
\hline Observations & $2,007,962$ & $2,007,962$ & $2,007,962$ & $2,007,305$ & $2,007,305$ & $2,007,305$ \\
\hline YEAR FE & $\mathrm{Y}$ & Y & $\mathrm{Y}$ & $\mathrm{Y}$ & Y & Y \\
\hline FIRM FE & $Y$ & Y & $\mathrm{Y}$ & $\mathrm{Y}$ & $Y$ & $Y$ \\
\hline FIRM SIZE CONTROLS & $\mathrm{Y}$ & $\mathrm{Y}$ & $\mathrm{Y}$ & $\mathrm{Y}$ & $\mathrm{Y}$ & $\mathrm{Y}$ \\
\hline INDUSTRY CONTROLS & $\mathrm{Y}$ & $\mathrm{Y}$ & $\mathrm{Y}$ & $\mathrm{Y}$ & $\mathrm{Y}$ & $\mathrm{Y}$ \\
\hline
\end{tabular}

Robust standard errors clustered at country-(34 TiVA) industry level, ${ }^{* * *} p<0.01,{ }^{* *} p<0.05,{ }^{*} p<0.1$

Firm size control reflects lagged employment. Industry controls include the (non-interacted) Policy Variable, GVC participation, Domestic sources of centrality, Fally's (2011) GVC Upstreamness and GVC Length measures, Exports of intermediates, Imports of intermediates, Industry production (as a measure of industry size), Balassa's Gross Revealed Comparative Advantage, and Koopman et al.'s (2014) Value-Added Revealed Comparative Advantage. 
Figure 4. Annual Increase in MFP for Frontier and Non-Frontier Firms for mean growth in Productivity of Buyers / Suppliers Labour Market Policy

Panel A: Flexible Employment Protection Legislation

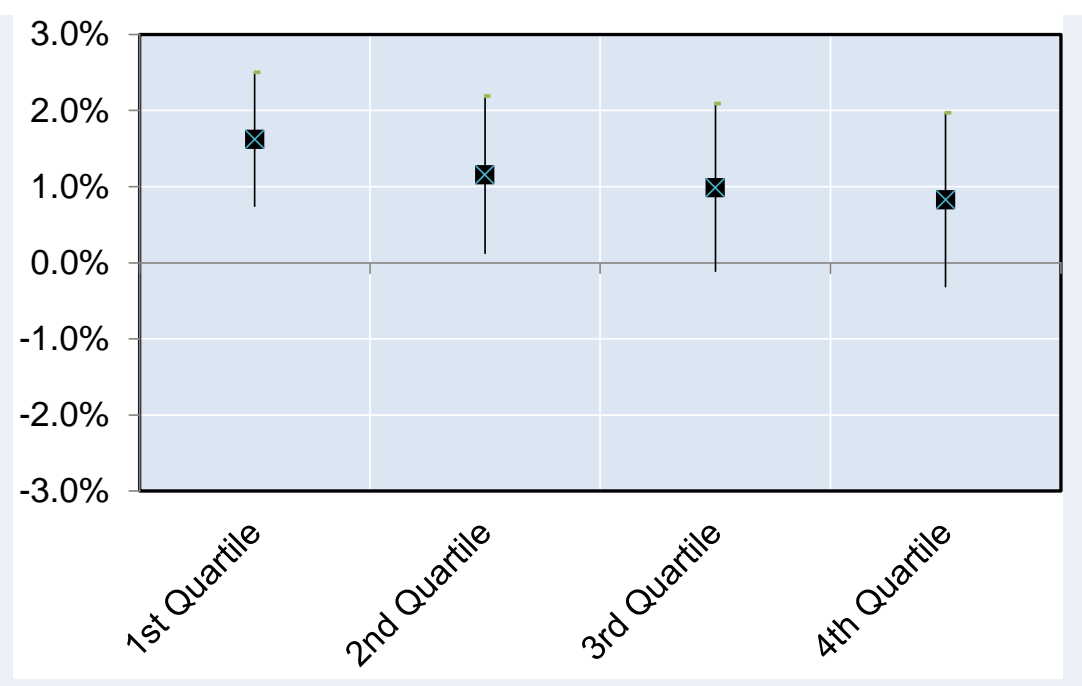

Panel B: Constraining Employment Protection Legislation

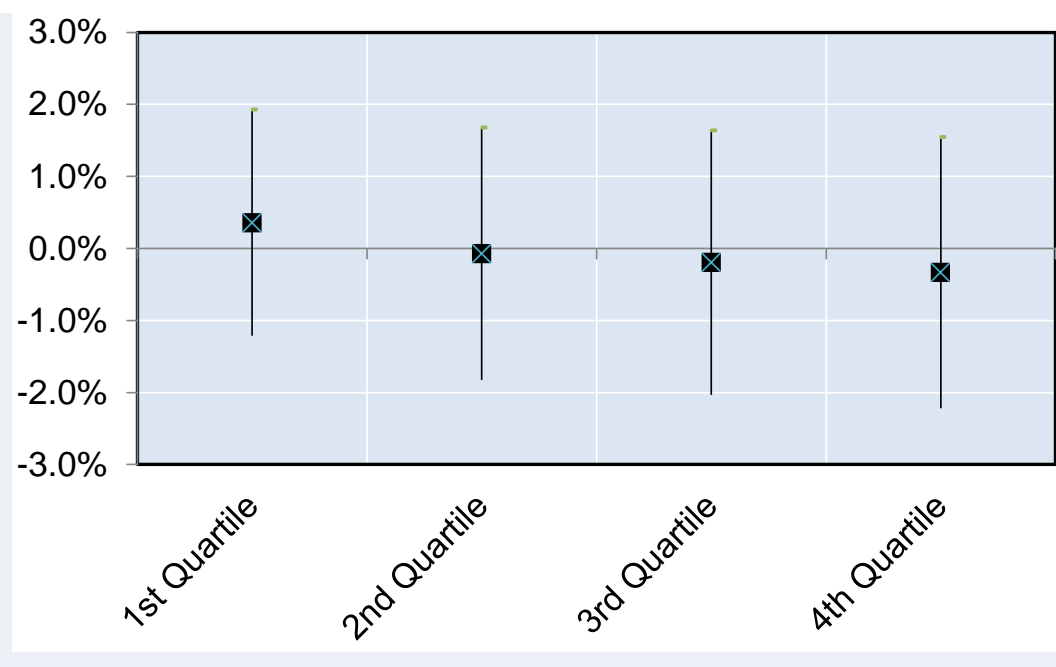

Note: Mean estimated (annual) correlations are reflected as points, with 95\% confidence interval bars. Shown for firms of different quartiles of initial MFP, with $1^{\text {st }}$ quartile representing the less productive initially to those most productive in the $4^{\text {th }}$ quartile. Based on estimates from regressions including industry controls, where employment protection legislation has been interacted with initial MFP quartile dummy variables interactions with Average Productivity (Centrality Weighted) of Buyers / Suppliers. The correlations are illustrated using the most flexible and least flexible labour market regimes in our sample: Flexible Employment Protection Legislation represents US 1998 values, constraining represents Portugal's 1998 values (the first year our policy variable is available). 
Table 16. What is the Role of Policy in Diffusion? Trade and Investment Barriers

\begin{tabular}{|c|c|c|c|c|c|c|}
\hline MFP Wooldridge & (1) & (2) & (3) & (4) & (5) & (6) \\
\hline Policy: & $\begin{array}{r}\text { - Barriers } t \\
\text { (Produc }\end{array}$ & $\begin{array}{l}\text { Trade and II } \\
\text { Market Regu }\end{array}$ & $\begin{array}{l}\text { lvestment } \\
\text { lations) }\end{array}$ & Cus & ms Complex & \\
\hline & Total & Forward & Backward & Total & Forward & Backward \\
\hline Centrality & $\begin{array}{c}0.084 \\
(0.099)\end{array}$ & $\begin{array}{c}0.131 \\
(0.099)\end{array}$ & $\begin{array}{l}-0.062 \\
(0.049)\end{array}$ & $\begin{array}{l}0.948^{* * *} \\
(0.261)\end{array}$ & $\begin{array}{l}0.570^{* * *} \\
(0.171)\end{array}$ & $\begin{array}{c}0.238 \\
(0.255)\end{array}$ \\
\hline Centrality * Policy & $\begin{array}{c}0.018 \\
(0.049)\end{array}$ & $\begin{array}{l}-0.022 \\
(0.038)\end{array}$ & $\begin{array}{l}0.108^{*} \\
(0.061)\end{array}$ & $\begin{array}{l}-0.191^{* \star *} \\
(0.059)\end{array}$ & $\begin{array}{c}-0.110^{* \star *} \\
(0.037)\end{array}$ & $\begin{array}{l}-0.027 \\
(0.070)\end{array}$ \\
\hline $\begin{array}{l}\text { Average Productivity (Centrality } \\
\text { Weighted) of Buyers / Suppliers }\end{array}$ & $\begin{array}{l}0.380 * * \\
(0.170)\end{array}$ & $\begin{array}{l}0.246^{*} \\
(0.144)\end{array}$ & $\begin{array}{c}0.084 \\
(0.132)\end{array}$ & $\begin{array}{l}1.065^{\star * *} \\
(0.243)\end{array}$ & $\begin{array}{l}1.160^{\star * \star} \\
(0.271)\end{array}$ & $\begin{array}{l}0.628^{* * *} \\
(0.229)\end{array}$ \\
\hline $\begin{array}{l}\text { Average Productivity (Centrality } \\
\text { Weighted) of Buvers / Suppliers * }\end{array}$ & 0.164 & 0.224 & 0.211 & $-0.132^{* *}$ & -0.070 & $-0.160^{* *}$ \\
\hline Policy & $(0.181)$ & $(0.176)$ & $(0.169)$ & $(0.062)$ & $(0.086)$ & $(0.064)$ \\
\hline Observations & $2,007,418$ & $2,007,418$ & $2,007,418$ & $2,276,699$ & $2,276,699$ & $2,276,699$ \\
\hline YEAR FE & $\mathrm{Y}$ & $\mathrm{Y}$ & Y & $\mathrm{Y}$ & $\mathrm{Y}$ & $\mathrm{Y}$ \\
\hline FIRM FE & $\mathrm{Y}$ & $\mathrm{Y}$ & Y & $\mathrm{Y}$ & Y & $\mathrm{Y}$ \\
\hline FIRM SIZE CONTROLS & Y & Y & Y & Y & Y & $\mathrm{Y}$ \\
\hline INDUSTRY CONTROLS & $\mathrm{Y}$ & $\mathrm{Y}$ & $\mathrm{Y}$ & $\mathrm{Y}$ & Y & Y \\
\hline
\end{tabular}


Table 17. What is the Role of Policy in Diffusion? Contract Enforcement

\begin{tabular}{|c|c|c|c|c|c|c|}
\hline MFP Wooldridge & (1) & (2) & (3) & (4) & (5) & (6) \\
\hline \multirow[t]{2}{*}{ Policy: } & \multicolumn{3}{|c|}{ Time to Enforce Contracts } & \multicolumn{3}{|c|}{ Intellectual Property Rights } \\
\hline & Total & Forward & Backward & Total & Forward & Backward \\
\hline Centrality & $\begin{array}{l}-0.081 \\
(0.711)\end{array}$ & $\begin{array}{c}-0.323 \\
(0.514)\end{array}$ & $\begin{array}{c}0.163 \\
(0.702)\end{array}$ & $\begin{array}{c}0.579 \\
(0.441)\end{array}$ & $\begin{array}{c}0.148 \\
(0.736)\end{array}$ & $\begin{array}{c}0.488 \\
(0.413)\end{array}$ \\
\hline Centrality * Policy & $\begin{array}{c}0.054 \\
(0.109)\end{array}$ & $\begin{array}{c}0.064 \\
(0.087)\end{array}$ & $\begin{array}{l}-0.007 \\
(0.102)\end{array}$ & $\begin{array}{l}-0.056 \\
(0.069)\end{array}$ & $\begin{array}{l}-0.038 \\
(0.045)\end{array}$ & $\begin{array}{l}-0.065 \\
(0.076)\end{array}$ \\
\hline $\begin{array}{l}\text { Average Productivity (Centrality } \\
\text { Weighted) of Buyers / Suppliers }\end{array}$ & $\begin{array}{l}2.191^{* * *} \\
(0.619)\end{array}$ & $\begin{array}{l}1.928^{\star * *} \\
(0.694)\end{array}$ & $\begin{array}{l}1.643^{* * *} \\
(0.610)\end{array}$ & $\begin{array}{c}-1.165^{\star \star \star} \\
(0.419)\end{array}$ & $\begin{array}{c}0.148 \\
(0.736)\end{array}$ & $\begin{array}{l}-2.062^{\star \star \star} \\
(0.528)\end{array}$ \\
\hline $\begin{array}{l}\text { Average Productivity (Centrality } \\
\text { Weighted) of Buyers / Suppliers * } \\
\text { Policy }\end{array}$ & $\begin{array}{l}-0.262^{\star \star \star} \\
(0.092)\end{array}$ & $\begin{array}{l}-0.173^{*} \\
(0.105)\end{array}$ & $\begin{array}{l}-0.255^{\star \star *} \\
(0.095)\end{array}$ & $\begin{array}{l}0.359^{* \star *} \\
(0.078)\end{array}$ & $\begin{array}{l}0.148 \\
(0.117)\end{array}$ & $\begin{array}{l}0.450^{\star * *} \\
(0.091)\end{array}$ \\
\hline Observations & $2,276,699$ & $2,276,699$ & $2,276,699$ & $2,446,048$ & $2,446,048$ & $2,446,048$ \\
\hline YEAR FE & $\mathrm{Y}$ & $\mathrm{Y}$ & $\mathrm{Y}$ & $\mathrm{Y}$ & $\mathrm{Y}$ & $\mathrm{Y}$ \\
\hline FIRM FE & $\mathrm{Y}$ & $\mathrm{Y}$ & $\mathrm{Y}$ & $\mathrm{Y}$ & Y & $\mathrm{Y}$ \\
\hline FIRM SIZE CONTROLS & $\mathrm{Y}$ & $\mathrm{Y}$ & $\mathrm{Y}$ & $\mathrm{Y}$ & Y & Y \\
\hline INDUSTRY CONTROLS & $\mathrm{Y}$ & $\mathrm{Y}$ & $\mathrm{Y}$ & $\mathrm{Y}$ & $\mathrm{Y}$ & $\mathrm{Y}$ \\
\hline
\end{tabular}

Robust standard errors clustered at country-(34 TiVA) industry level, ${ }^{* *} p<0.01,{ }^{* *} p<0.05,{ }^{*} p<0.1$

Firm size control reflects lagged employment. Industry controls include the (non-interacted) Policy Variable, GVC participation, Domestic sources of centrality, Fally's (2011) GVC Upstreamness and GVC Length measures, Exports of intermediates, Imports of intermediates, Industry production (as a measure of industry size), Balassa's Gross Revealed Comparative Advantage, and Koopman et al.'s (2014) Value-Added Revealed Comparative Advantage. 
Table 18. What is the Role of Policy in Diffusion? Barriers to Entrepreneurship and Access to Finance

\begin{tabular}{|c|c|c|c|c|c|c|}
\hline \multirow[t]{2}{*}{ MFP Wooldridge } & \multicolumn{2}{|l|}{ (1) } & (3) & (4) & (5) & (6) \\
\hline & \multicolumn{3}{|c|}{$\begin{array}{l}\text { Barriers to Entrepreneurship } \\
\text { (Product Market Regulations) }\end{array}$} & \multicolumn{3}{|c|}{ Access to Finance } \\
\hline & Total & Forward & Backward & Total & Forward & Backward \\
\hline Centrality & $\begin{array}{c}0.128 \\
(0.098)\end{array}$ & $\begin{array}{c}0.114 \\
(0.122)\end{array}$ & $\begin{array}{l}-0.001 \\
(0.060)\end{array}$ & $\begin{array}{c}0.201 \\
(0.249)\end{array}$ & $\begin{array}{c}0.002 \\
(0.203)\end{array}$ & $\begin{array}{c}0.062 \\
(0.051)\end{array}$ \\
\hline Centrality * Policy & $\begin{array}{c}0.009 \\
(0.018)\end{array}$ & $\begin{array}{l}-0.005 \\
(0.017)\end{array}$ & $\begin{array}{l}0.032 \\
(0.020)\end{array}$ & $\begin{array}{c}0.010 \\
(0.048)\end{array}$ & $\begin{array}{c}0.002 \\
(0.037)\end{array}$ & $\begin{array}{l}0.062 \\
(0.051)\end{array}$ \\
\hline $\begin{array}{l}\text { Average Productivity (Centrality } \\
\text { Weighted) of Buyers / Suppliers }\end{array}$ & $\begin{array}{c}0.911^{* * *} \\
(0.212)\end{array}$ & $\begin{array}{l}0.700^{* * *} \\
(0.199)\end{array}$ & $\begin{array}{l}0.576^{\star * *} \\
(0.201)\end{array}$ & $\begin{array}{l}-0.574^{*} \\
(0.317)\end{array}$ & $\begin{array}{c}0.157 \\
(0.471)\end{array}$ & $\begin{array}{c}-1.374^{\star \star \star} \\
(0.447)\end{array}$ \\
\hline $\begin{array}{l}\text { Average Productivity (Centrality } \\
\text { Weighted) of Buyers / Suppliers * } \\
\text { Policy }\end{array}$ & $\begin{array}{l}-0.196 * * \\
(0.089)\end{array}$ & $\begin{array}{l}-0.150 * \\
(0.083)\end{array}$ & $\begin{array}{l}-0.168^{*} \\
(0.091)\end{array}$ & $\begin{array}{l}0.287^{* * *} \\
(0.068)\end{array}$ & $\begin{array}{l}0.173^{* *} \\
(0.081)\end{array}$ & $\begin{array}{l}0.368^{\star * *} \\
(0.082)\end{array}$ \\
\hline Observations & $2,007,418$ & $2,007,418$ & $2,007,418$ & $2,446,048$ & $2,446,048$ & $2,446,048$ \\
\hline YEAR FE & $\mathrm{Y}$ & $\mathrm{Y}$ & $\mathrm{Y}$ & $\mathrm{Y}$ & $\mathrm{Y}$ & $\mathrm{Y}$ \\
\hline FIRM FE & $\mathrm{Y}$ & Y & Y & $\mathrm{Y}$ & $\mathrm{Y}$ & Y \\
\hline FIRM SIZE CONTROLS & $\mathrm{Y}$ & Y & $\mathrm{Y}$ & Y & Y & $\mathrm{Y}$ \\
\hline INDUSTRY CONTROLS & $Y$ & Y & $Y$ & $Y$ & $Y$ & $Y$ \\
\hline $\begin{array}{l}\text { Robust standard errors clustered a } \\
\text { Firm size control reflects lagged er } \\
\text { participation, Domestic sources o } \\
\text { Exports of intermediates, Imports } \\
\text { Gross Revealed Comparative Ad } \\
\text { Advantage. }\end{array}$ & $\begin{array}{l}\text { ountry-(34 T } \\
\text { oyment. Ind } \\
\text { entrality, Fa } \\
\text { termediate } \\
\text { tage, and }\end{array}$ & $\begin{array}{l}\text { VA) industry } \\
\text { istry controls } \\
\text { ly's (2011) } \\
\text { Industry pr } \\
\text { loopman et }\end{array}$ & $\begin{array}{l}\text { level, }{ }^{\star \star \star} p<0 \\
\text { include the } \\
\text { jVC Upstrea } \\
\text { duction (as } \\
\text { al.'s (2014) }\end{array}$ & $\begin{array}{l}.01,{ }^{* *} p<0.0 \\
\text { inon-interact } \\
\text { imness and } \\
\text { measure of } \\
\text { Value-Added }\end{array}$ & $\begin{array}{l}5,{ }^{*} p<0.1 \\
\text { d) Policy Va } \\
\text { GVC Length } \\
\text { industry size } \\
\text { Revealed }\end{array}$ & $\begin{array}{l}\text { iable, GVC } \\
\text { measures, } \\
\text {, Balassa's } \\
\text { omparative }\end{array}$ \\
\hline
\end{tabular}

\section{Conclusions}

88. This paper examines how the profound changes in the structure of GVCs over recent years impact firm productivity growth. First, we use "centrality" metrics to measure position within Global Value Chains (GVCs), reflecting central hubs and peripheral country-sectors, and link changes in centrality to firm productivity growth across countries. Second, we examine whether the composition of foreign buyers and suppliers matters for productivity. We supplement the standard centrality metrics by examining changes in the average productivity (centrality weighted) of foreign buyers / suppliers.

89. We find that the changing structure of GVCs can play a role in the catch up of firms. Increasing centrality is associated with faster productivity growth of smaller or non-frontier firms and also with overall firm productivity growth in post-2004 EU members or smaller countries. But these correlations weaken with firm size or proximity to the frontier, such that there is no correlation over all firms in the data. In particular, we find either insignificant or even negative correlations for larger or frontier firms or firms in larger countries or the rest of Factory Europe (excluding post-2004 EU members). Consequently becoming more influential within GVC networks appears to be important for the catch-up of non-frontier firms and economies. Whereas for those firms or 
economies that are already large or near the frontier, becoming more influential does not appear to impact productivity.

90. The composition of buyers matters for firms in our data overall, but this composition is particularly important for the catch up of firms. Both supplying or buying from faster growing foreign sectors is correlated with faster productivity growth of smaller or non-frontier firms, with these correlations weakening with firm size or proximity to the frontier. But these correlations are only present for all firms in terms of the productivity of buyers, and also only in larger economies or the rest of Factory Europe (excluding post-2004 EU members). This may in part be due to poorer Orbis coverage of firms in smaller economies and post-2004 EU members.

91. The stronger correlations we see for smaller and non-frontier firms suggest that the domestic spillovers of GVCs may be at least as important as the impacts on those firms directly involved in GVCs. Whilst our data does not allow us to test this precisely, we find some support for this - firm productivity growth is stronger in sectors that have stronger indirect linkages to highly productive foreign sectors (e.g. as domestic suppliers of exporters) compared to those sectors with stronger direct linkages (e.g. as exporters). This is consistent with a narrative where foreign firms share knowledge with domestic suppliers, with spillovers transmitted down domestic supply chains. However, clearly this is an avenue through which further work on firm-to-firm linkages would be beneficial.

92. The link between the changing structure of GVCs and firm productivity is dependent upon the policy environment. We find that framework policies, particularly flexible labour markets, matter for the diffusion of productivity. In economies with flexible labour markets the diffusion of foreign productivity growth to non-frontier firms is more strongly present, and weakens with the stringency of employment regulation. We find no evidence of productivity growth of non-frontier or frontier firms for those economies in our sample with the least flexible labour markets. In addition, the correlation with firm productivity is strengthened in environments with stronger investor protection, through contract enforcement and intellectual property protection. Finally, we find that policies commonly associated with trade participation, such as the availability of credit and the complexity of customs procedures, are associated with stronger productivity diffusion.

93. Our results suggest that traditional policy measures to encourage integration and influence within GVCs (such as trade facilitation, export guarantees etc.) are important for the productivity of non-frontier or smaller firms, and also firms in smaller or nonfrontier economies. . Our results also suggest the composition of buyer and supplier networks appear to also matter for spillovers to non-frontier firms and also for firms overall in larger or higher-income economies. These results suggest that policies that facilitate GVC integration may be needed, which encourage the formation of linkages with highly productive foreign firms and economies. 


\section{References}

Acemoglu, D. et al. (2012), "The network origins of aggregate fluctuations", Econometrica, 80(5), pp. 1977-2016.

Acemoglu, D., U. Akcigit and W. Kerr (2015), "Networks and the Macroeconomy: An Empirical Exploration", NBER Working Paper, No. 21344.

Alatas, V. et al. (2016), "Network Structure and the Aggregation of Information: Theory and Evidence from Indonesia”, American Economic Review, 106(7), pp. 1663-1704.

Amador, J. and S. Cabral (2017), "Networks of Value-Added Trade", World Economy, 40(7), pp. 12911313.

Amiti, M. and J. Konings (2007), “Trade Liberalization, Intermediate Inputs, and Productivity: Evidence from Indonesia”, American Economic Review, Vol. 97, No. 5, pp. 1611-38.

Andrews, D., C. Criscuolo and P. Gal (2016), "The Best versus the Rest: The Global Productivity Slowdown, Divergence across Firms and the Role of Public Policy", OECD Productivity Working Papers No. 5, OECD Publishing, Paris.

Antras, P. and S. Yeaple (2014), "Multinational Firms and the Structure of International Trade", Handbook of International Economics, Vol. 4, pp. 55-130.

Arnold, J, B. Javorcik and A. Mattoo (2011), "Does services liberalization benefit manufacturing firms?: Evidence from the Czech Republic", Journal of International Economics, Vol. 85, No. 1, pp. 136146.

Arnold, J. et al. (2016), "Services Reform and Manufacturing Performance: Evidence from India", Economic Journal, Vol. 126, Issue 590, pp. 1-39.

Atalay, E. (2015), “How Important Are Sectoral Shocks?”, Mimeo.

Atkin, D. et al. (2017), "Exporting and Firm Performance: Evidence from a Randomised Experiment", Quarterly Journal of Economics, 132(2), pp. 551-615.

Auer, R., A. Levchenko and P. Sauré (2016), "International Inflation Spillovers Through Input Linkages", Mimeo.

Bajgar, M. and B. Javorcik (2016), "Climbing the Rungs of the Quality Ladder: FDI and Domestic Exporters in Romania", Mimeo.

Bajgar, M., C. Criscuolo and J. Timmis (2017), "To Use or Not to Use (and How to Use): Coverage and Performance of Orbis Data", Mimeo.

Baldwin, R. (2012), “Trade and industrialisation after globalisation's 2nd unbundling: How building and joining a supply chain are different and why it matters", CEPR Discussion Paper, No. 9103. 
Baldwin, R. and A. Venables (2013), "Spiders and snakes: Offshoring and agglomeration in the global economy", Journal of International Economics, 90, pp. 245-254.

Banerjee, A. et al. (2016), “Gossip: Identifying Central Individuals in a Social Network”, Mimeo.

Barrot, J-N and J. Sauvagnat (2016), "Input Specificity and the Propagation of Idiosyncratic Shocks in Production Networks", Quarterly Journal of Economics, 131(3), pp. 1543-1592.

Bas, M. and V. Strauss-Kahn (2015), "Input-trade liberalization, export prices and quality upgrading" Journal of International Economics, Vol. 95, No. 2, pp. 250-262.

Beaman, L. et al. (2015), “Can Network Theory-based Targeting Increase Technology Adoption?", Mimeo.

Bernard, A. et al. (2016), "Global Firms”, NBER Working Paper, No. 22727.

Bernard, A. et al. (2014), "Multi-Product Exporters and the Margins of Trade", Japanese Economic Review, 65(2), pp. 142-157.

Bernard, A. et al. (2011a), "The Empirics of Firm Heterogeneity and International Trade", NBER Working Paper, No. 17627.

Bernard, A. et al. (2011b), "Multi-Product Firms and Trade Liberalization", Quarterly Journal of Economics, Vol. 126(3), pp. 1271-1318.

Boehm, C., A. Flaaen, and N. Pandalai-Naya (2015), "Input Linkages and the Transmission of Shocks: Firm-Level Evidence from the 2011 Tōhoku Earthquake," Finance and Economics Discussion Series 2015-094, Washington: Board of Governors of the Federal Reserve System.

Brin, S. and L. Page (1998), "The Anatomy of a Large-Scale Hypertextual Web Search Engine," Computer Networks, 30, pp. 107-117.

Brynjolfsson, E. and L. Hitt (2000), "Beyond Computation: Information Technology, Organizational Transformation and Business Performance", Journal of Economic Perspectives, Vol. 14, No. 4, pp. 23-48.

Caie, J., A. Janvry and E. Sadoulet (2015). "Social Networks and the Decision to Insure", American Economic Journal: Applied Economics, 7(2), pp. 81-108.

Carvalho, V. (2012), “A Survey Paper on Recent Developments of Input-Output Analysis”, Complexity Research Initiative for Systemic Instabilities.

Carvalho, V. (2014), "From Micro to Macro via Production Networks", Journal of Economic Perspectives, 28(4), pp. 23-47.

Carvalho, V. and B. Grassi (2016), "Large Firm Dynamics and the Business Cycle", Cambridge Working Papers in Economics, No. 1556.

Carvalho, V. and N. Voigtländer (2015), "Input Diffusion and the Evolution of Production Networks", Mimeo.

Cerina, F. et al. (2015), “World Input-Output Network”, Plos One, 10(7): e0134025. 
Chang, Y. and S. Hwang (2015), "Asymmetric Phase Shifts in U.S. Industrial Production Cycles", Review of Economics and Statistics, 97(1), pp. 116-133.

Conley, T. and C. Udry (2010), "Learning about a New Technology: Pineapple in Ghana", American Economic Review, 100(1), pp. 35-69.

Cravino, J. and A. Levchenko (2016), "Multinational Firms and International Business Cycle Transmission”, NBER Working Paper, No. 22498

Criscuolo, C., J. Timmis and N. Johnstone (2016), "The Relationship between GVCs and Productivity", Background Paper to the 2016 Conference of the Global Forum on Productivity. Available from: http://www.oecd.org/global-forumproductivity/events/Relashionship_btween_GVCs_and_productivity_6_09_2016.pdf

Criscuolo, C. and J. Timmis (2018), "GVCs and centrality: Mapping key hubs, spokes and the periphery", OECD Productivity Working Papers, No. 12, http://dx.doi.org/10.1787/d4a9bd6f-en.

De Backer, K. and S. Miroudot (2017), "Multinational Enterprises and Global Value Chains: New insights on the trade -investment nexus", DSTI/CIIE(2017)1

De Backer, K. and S. Miroudot (2013), "Mapping Global Value Chains" OECD Trade Policy Papers, No. 159, OECD Publishing, Paris. DOI: http://dx.doi.org/10.1787/5k3v1trgnbr4-en

De Benedictis, L. et al. (2013), "Network Analysis of World Trade using the BACI-CEPII dataset", CEPII Working Paper, No. 2013-24.

De Loecker, J. and F. Warzynski (2012), "Markups and Firm-Level Export Status", American Economic Review, 102(6), pp. 2437-2471.

De Loecker, J. and J. Van Biesebroeck (2016), ““"Effect of international competition on firm productivity and market power", NBER Working Paper, No. 21994

Di Giovanni, J., A.A. Levchenko and I. Medjean (2016), "The Micro Origins of International Business Cycle Comovement", NBER Working Paper, No. 21885.

Di Giovanni, J., A.A. Levchenko and I. Medjean (2014), "Firms, Destinations and Aggregate Fluctuations", Econometrica, 82(4), pp. 1303-1340.

Di Maggio, M. et al. (2016), "The Relevance of Broker Networks for Information Diffusion in the Stock Market", Swiss Finance Institute Research Paper Series, No. 16-63.

Fally, T. (2011), "On the Fragmentation of Production in the U.S.”, Mimeo

Foerster, A. P-D. Sarte and M. Watson (2011), "Sectoral versus Aggregate Shocks: A Structural Factor Analysis of Industrial Production", Journal of Political Economy, 119(1), pp. 1-38.

Gabaix, X. (2011), “The Granular Origins of Aggregate Fluctuations”, Econometrica, 79(3), pp. 733772.

Gal, P. (2013), "Measuring Total Factor Productivity at the Firm Level using OECD-Orbis", OECD Economics Department Working Paper, No. 1049. 
Gal, P. and A. Hijzen (2016), "The Short-term Impact of Product Market Reforms: A Cross-country Firm Level Analysis", OECD Economics Department Working Paper, No. 1311.

Glasserman, P. and H. Young (2016), "Contagion in Financial Networks", Journal of Economic Literature, 54(3), pp. 779-831.

Goldberg, P.K., A.K. Khandelwal, N. Pavenik and P. Topalova (2010), "Imported Intermediate Inputs and Domestic Product Growth: Evidence from India" Quarterly Journal of Economics, Vol. 125, No. 4, pp. 1727-67.

Görg, H. et al. (2016), "Firm Size Distribution and Employment Fluctuations: Theory and Evidence", IZA Discussion Paper Series, No. 10371.

Gourdon, J., P. Kowalksi and J. Gonzalez (2016), "Sectoral Analysis of Global Value Chains and Developing Countries - Scoping Paper", TAD/TC/WP(2016)5.

Grossman, G. M. and E. Rossi-Hansberg (2008), "Trading Tasks: A Simple Theory of Offshoring", American Economic Review, Vol. 95, No. 5, pp. 1978-1997.

Guadalupe, M., O. Kuzmina and C. Thomas (2012), "Innovation and Foreign Ownership", American Economic Review, Vol. 102, No. 7, pp. 3594-3627.

Hahn, Y. et al. (2015). "Teams, Organization and Education Outcomes: Evidence from a Field Experiment in Bangladesh". Centre for Economic Policy Research Discussion Paper, No. 10631.

Harding, T. and B. Javorcik (2012), "Foreign Direct Investment and Export Upgrading", Review of Economics and Statistics, 94(4), pp. 964-980.

Holmes, T. and J. Stevens (2012). "Exports, Borders, Distance, and Plant Size”, Journal of International Economics, 88, pp.91-103.

Imbs, J and L. Pauwels (2017), “Fundamental moments”, Mimeo.

Inklaar, R and M.P. Timmer (2014). "The Relative Price of Services", Review of Income and Wealth, . 60(4), pp. 727-746.

Javorcik, B.S. (2004), "Does Foreign Direct Investment Increase the Productivity of Domestic Firms? In Search of Spillovers Through Backward Linkages," American Economic Review, 94(3): 605-627

Kalemli-Ozcan, S., B. Sorensen, C. Villegas-Sanchez, V. Volosovych and S. Yesiltas (2015), "How to Construct Nationally Representative Firm Level Data from the Orbis Global Database", NBER Working Papers, No. 21558.

Kleinert, J., J. Martin and F. Toubal (2015, "The Few Leading the Many: Foreign Affiliates and Business Cycle Comovement”, American Economic Journal, 7(4), pp. 134-159.

Koopman, R., Z. Wang and S-J. Wei (2014). "Tracing Value-Added and Double Counting in Gross Exports", American Economic Review, 104(2), pp. 459-494.

Jackson, M., B. Rogers and Y. Zenou (2017), "The Economic Consequences of Social-Network Structure", Journal of Economic Literature, 55(1), pp. 49-95. 
Loungani, P. et al. (2017), "World Trade in Services: Evidence from A New Dataset", IMF Working Paper, WP/17/77.

Lucas, R. (1977), “Understanding Business Cycles”, Carnegie-Rochester Conference Series on Public Policy, 5(1), pp. 7-29.

MacGarvie, M. (2006), "Do Firms Learn from International Trade?", Review of Economics and Statistics, 88(1), pp. 46-60.

Magerman, G. et al. (2016), "Heterogeneous firms and the micro origins of aggregate fluctuations", $N B B$ Working Paper, No. 312.

Nunn, N. (2007), "Relationship-Specificity, Incomplete contracts, and the Pattern of Trade", Quarterly Journal of Economics, 122(2), pp. 569-600.

OECD (2013), "Interconnected Economies: Benefiting from Global Value Chains", OECD Publishing, Paris. DOI: http://dx.doi.org/10.1787/9789264189560-en

OECD, World Bank and WTO (2014), "Global Value Chains: Challenges, Opportunities, and Implications for Policy", Report Prepared for Submission to the G20 Trade Ministers Meeting Sydney, Australia.

Saia, A., D. Andrews and S. Albrizio (2015), "Productivity Spillovers from the Global Frontier and Public Policy: Industry-Level Evidence", OECD Economics Department Working Papers, No. 1238.

Samaniego, R. (2013), "Knowledge spillovers and intellectual property rights", International Journal of Industrial Organization, 31(1), pp. 50-63.

Santoni, G. and D. Taglioni (2015), "Networks and structural integration in global value chains", in J. Amador and F. Di Mauro (eds.) The Age of GVCs: Maps and Policy Issues, CEPR Press.

Smith, R. (2014), “Chemical Process: Design and Integration”, John Wiley \& Sons.

Sturgeon, T. and R. Lester (2004), 'The New Global Supply-base: Challenges for Local Suppliers in East Asia', in S. Yusuf, A. Altaf, and K. Nabeshima (eds), Global Production Networking and Technological Change in East Asia, New York: Oxford University Press.

The Economist (2013), "Home or abroad? Herd instinct", Jan $19^{\text {th }} 2013$.

Timmer, M. et al. (2015), "An Illustrated User Guide to the World Input-Output Database: the Case of Global Automotive Production”, Review of International Economics, 23(3), pp. 575-605.

Wasserman, S., and K. Faust (1994), "Social Network Analysis: Methods and. Applications", Cambridge University Press, Cambridge, ENG and New York.

Watts, D. and S. Strogatz (1998), “Collective dynamics of 'small-world' networks”, Nature, 393, pp. 440442. 
Annex A.

\section{Additional Figures and Tables}

Table A.1. Heterogeneity by country \& firm type: Post-2004 EU Members \& Other Factory Europe - Frontier vs Non-frontier

\begin{tabular}{|c|c|c|c|c|c|c|}
\hline \multirow{3}{*}{ MFP Wooldridge } & \multicolumn{3}{|c|}{$\begin{array}{l}\text { Post-2004 EU Members Countries - } \\
\text { Frontier vs Non-Frontier }\end{array}$} & \multicolumn{3}{|c|}{$\begin{array}{c}\text { Other Factory Europe - Frontier vs } \\
\text { Non-Frontier }\end{array}$} \\
\hline & (7) & (8) & (9) & (10) & (11) & (12) \\
\hline & Total & Forward & Backward & Total & Forward & Backward \\
\hline \multirow[t]{2}{*}{ Centrality } & $20.893^{\star \star *}$ & $31.453^{\star * *}$ & $13.115^{* * *}$ & 0.214 & 0.258 & 0.452 \\
\hline & $(1.887)$ & $(4.443)$ & $(1.607)$ & $(0.315)$ & $(0.232)$ & $(0.320)$ \\
\hline \multirow[t]{2}{*}{ Centrality * Initial Firm MFP } & $-1.481^{\star * *}$ & $-2.554^{* * *}$ & $-0.924^{\star * *}$ & -0.011 & -0.006 & $-0.049^{*}$ \\
\hline & $(0.275)$ & $(0.374)$ & $(0.213)$ & $(0.027)$ & $(0.018)$ & $(0.028)$ \\
\hline Average Productivity (Centrality Weighted) of & $6.847^{* * *}$ & $5.254^{\star \star \star}$ & $6.561^{* \star *}$ & $4.127^{\star \star \star}$ & $4.388^{\star \star \star}$ & $3.425^{\star \star \star}$ \\
\hline Buyers / Suppliers & $(0.917)$ & $(1.151)$ & $(0.832)$ & $(0.641)$ & $(0.637)$ & $(0.558)$ \\
\hline $\begin{array}{l}\text { Average Productivity (Centrality Weighted) of } \\
\text { Buyers / Suppliers * Initial Firm MFP }\end{array}$ & $\begin{array}{c}-0.601^{* * *} \\
(0.078)\end{array}$ & $\begin{array}{c}-0.426^{* * *} \\
(0.106)\end{array}$ & $\begin{array}{c}-0.633^{\star * *} \\
(0.076)\end{array}$ & $\begin{array}{c}-0.330^{* * *} \\
(0.054)\end{array}$ & $\begin{array}{c}-0.358^{* * *} \\
(0.053)\end{array}$ & $\begin{array}{c}-0.288^{* * *} \\
(0.048)\end{array}$ \\
\hline Observations & 245,124 & 245,124 & 245,124 & $2,019,522$ & $2,019,522$ & $2,019,522$ \\
\hline YEAR FE & $\mathrm{Y}$ & $\mathrm{Y}$ & $\mathrm{Y}$ & Y & $\mathrm{Y}$ & $\mathrm{Y}$ \\
\hline FIRM FE & $\mathrm{Y}$ & $\mathrm{Y}$ & $\mathrm{Y}$ & $\mathrm{Y}$ & $\mathrm{Y}$ & Y \\
\hline FIRM SIZE CONTROLS & $\mathrm{Y}$ & $\mathrm{Y}$ & $\mathrm{Y}$ & Y & $\mathrm{Y}$ & Y \\
\hline INDUSTRY CONTROLS & $\mathrm{Y}$ & $\mathrm{Y}$ & $\mathrm{Y}$ & Y & Y & Y \\
\hline
\end{tabular}


Table A.2. Heterogeneity by country \& firm type: Large \& Small Countries - Frontier vs Non-frontier

\begin{tabular}{|c|c|c|c|c|c|c|}
\hline \multirow{3}{*}{ MFP Wooldridge } & \multicolumn{3}{|c|}{$\begin{array}{c}\text { Smaller Countries - Frontier vs } \\
\text { Non-Frontier }\end{array}$} & \multicolumn{3}{|c|}{$\begin{array}{c}\text { Larger Countries - Frontier vs Non- } \\
\text { Frontier }\end{array}$} \\
\hline & $(7)$ & (8) & (9) & $(10)$ & $(11)$ & (12) \\
\hline & Total & Forward & Backward & Total & Forward & Backward \\
\hline \multirow[t]{2}{*}{ Centrality } & 1.612 & 0.612 & 2.373 & $1.275^{\star *}$ & 0.512 & $1.618^{* * *}$ \\
\hline & (1.723) & (1.114) & (1.571) & $(0.597)$ & $(0.339)$ & $(0.611)$ \\
\hline \multirow[t]{2}{*}{ Centrality * Initial Firm MFP } & -0.078 & -0.002 & -0.200 & $-0.108^{* *}$ & -0.047 & $-0.136^{\star * *}$ \\
\hline & $(0.142)$ & $(0.094)$ & $(0.134)$ & $(0.049)$ & $(0.029)$ & $(0.048)$ \\
\hline $\begin{array}{l}\text { Average Productivity (Centrality Weighted) of } \\
\text { Buyers / Suppliers }\end{array}$ & $\begin{array}{c}5.117^{\star \star \star} \\
(0.588)\end{array}$ & $\begin{array}{c}4.969^{* * *} \\
(0.568)\end{array}$ & $\begin{array}{c}4.683^{\star \star \star} \\
(0.549)\end{array}$ & $\begin{array}{c}6.198^{\star * *} \\
(0.851)\end{array}$ & $\begin{array}{c}6.774^{\star * *} \\
(0.769)\end{array}$ & $\begin{array}{c}4.662^{* \star *} \\
(0.774)\end{array}$ \\
\hline $\begin{array}{l}\text { Average Productivity (Centrality Weighted) of } \\
\text { Buyers / Suppliers * Initial Firm MFP }\end{array}$ & $\begin{array}{l}-0.466^{\star \star *} \\
(0.051)\end{array}$ & $\begin{array}{c}-0.450^{* * *} \\
(0.050)\end{array}$ & $\begin{array}{l}-0.433^{\star \star \star} \\
(0.047)\end{array}$ & $\begin{array}{l}-0.497^{\star \star \star} \\
(0.071)\end{array}$ & $\begin{array}{c}-0.514^{* \star *} \\
(0.065)\end{array}$ & $\begin{array}{c}-0.419^{\star \star *} \\
(0.066)\end{array}$ \\
\hline Observations & 450,779 & 450,779 & 450,779 & $1,995,269$ & $1,995,269$ & $1,995,269$ \\
\hline YEAR FE & Y & Y & Y & Y & Y & $\mathrm{Y}$ \\
\hline FIRM FE & Y & Y & Y & Y & Y & Y \\
\hline FIRM SIZE CONTROLS & Y & Y & Y & Y & Y & Y \\
\hline INDUSTRY CONTROLS & Y & Y & Y & Y & Y & Y \\
\hline
\end{tabular}

Table A.3. Heterogeneity by sector \& firm type: Manufacturing \& Services - Frontier vs

\begin{tabular}{|c|c|c|c|c|c|c|}
\hline \multirow{3}{*}{ MFP Wooldridge } & \multicolumn{3}{|c|}{ Services - Frontier vs Non-Frontier } & \multicolumn{3}{|c|}{$\begin{array}{c}\text { Manufacturing - Frontier vs Non- } \\
\text { Frontier }\end{array}$} \\
\hline & (1) & (2) & (3) & (4) & (5) & (6) \\
\hline & Total & Forward & Backward & Total & Forward & Backward \\
\hline \multirow[t]{2}{*}{ Centrality } & $1.485^{\star \star}$ & $0.791^{* \star \star}$ & $1.739^{\star \star}$ & 1.551 & -0.211 & $1.612^{\star}$ \\
\hline & $(0.677)$ & $(0.299)$ & $(0.845)$ & $(1.057)$ & $(1.185)$ & $(0.929)$ \\
\hline \multirow[t]{2}{*}{ Centrality * Initial Firm MFP } & $-0.100^{*}$ & $-0.052^{\star \star}$ & $-0.150^{\star *}$ & $-0.171^{\star *}$ & -0.064 & $-0.137^{*}$ \\
\hline & $(0.051)$ & $(0.025)$ & $(0.068)$ & $(0.087)$ & $(0.087)$ & $(0.078)$ \\
\hline \multirow{2}{*}{$\begin{array}{l}\text { Average Productivity (Centrality Weighted) } \\
\text { of Buyers / Suppliers }\end{array}$} & $6.208^{\star * \star}$ & $6.477^{\star \star \star}$ & $4.738^{\star \star *}$ & $6.792^{* \star *}$ & $7.226^{\star * *}$ & $5.679^{\star * *}$ \\
\hline & $(0.896)$ & $(0.838)$ & $(0.750)$ & $(0.942)$ & $(0.694)$ & $(0.943)$ \\
\hline \multirow{2}{*}{$\begin{array}{l}\text { Average Productivity (Centrality Weighted) } \\
\text { of Buyers / Suppliers * Initial Firm MFP }\end{array}$} & $-0.507^{\star \star \star}$ & $-0.495^{\star * *}$ & $-0.433^{\star \star \star}$ & $-0.583^{* * *}$ & $-0.612^{* \star *}$ & $-0.510^{\star * *}$ \\
\hline & $(0.074)$ & $(0.062)$ & $(0.069)$ & $(0.078)$ & $(0.061)$ & $(0.079)$ \\
\hline Observations & $1,331,042$ & $1,331,042$ & $1,331,042$ & $1,114,983$ & $1,114,983$ & $1,114,983$ \\
\hline YEAR FE & Y & Y & Y & Y & Y & Y \\
\hline FIRM FE & Y & Y & Y & Y & $Y$ & $Y$ \\
\hline FIRM SIZE CONTROLS & Y & Y & Y & Y & Y & Y \\
\hline INDUSTRY CONTROLS & Y & Y & $\mathrm{Y}$ & Y & Y & Y \\
\hline
\end{tabular}


Table A.4. Decomposition of Average Productivity (Centrality Weighted) of Buyers and Suppliers

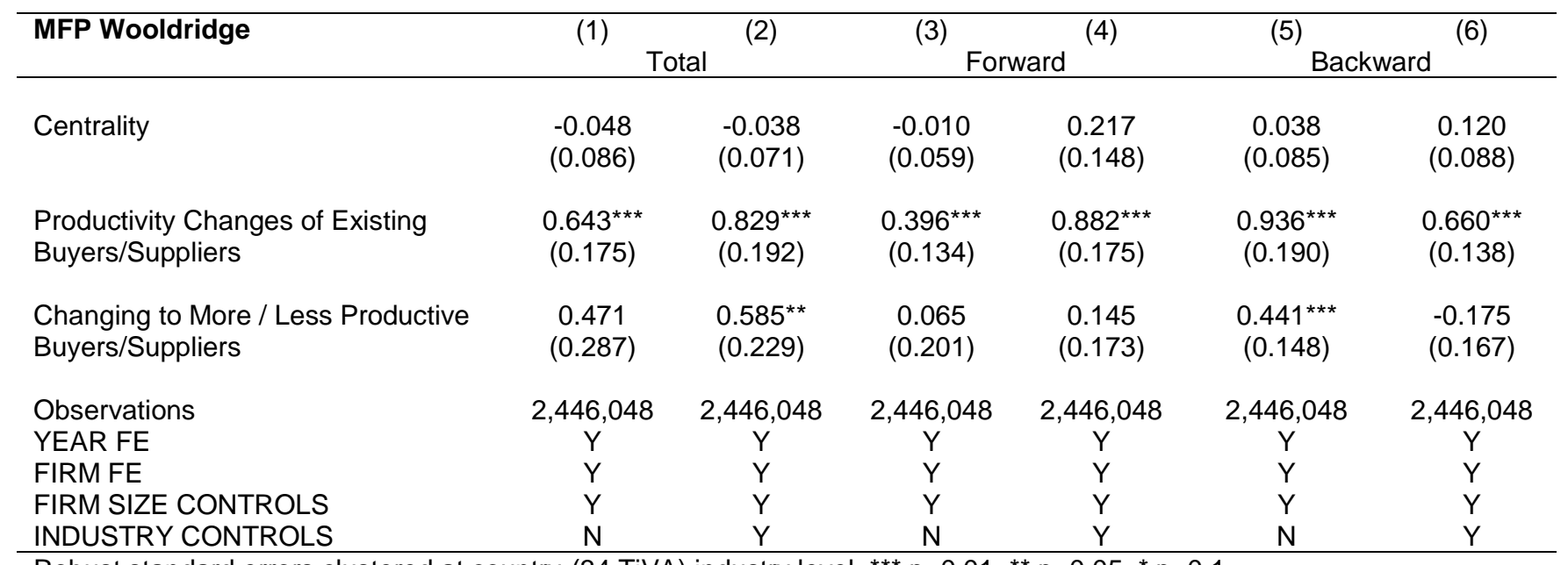

Robust standard errors clustered at country-(34 TiVA) industry level, ${ }^{\star \star *} p<0.01,{ }^{* \star} p<0.05,{ }^{*} p<0.1$

Firm size control reflects lagged employment. Industry controls include Domestic sources of centrality, Fally's (2011) GVC Upstreamness and GVC Length measures, Exports of intermediates, Imports of intermediates, Industry production (as a measure of industry size), Balassa's Gross Revealed Comparative Advantage, and Koopman et al.'s (2014) Value-Added Revealed Comparative Advantage.

Table A.5. First Stage of Indstrumental Variable Estimation

\begin{tabular}{|c|c|c|c|c|c|c|}
\hline \multirow{2}{*}{ First Stage - Centrality: } & (1) & $(2)$ & \multirow{2}{*}{\multicolumn{2}{|c|}{ Forward }} & \multicolumn{2}{|c|}{$\begin{array}{l}\text { (5) } \\
\text { Backward }\end{array}$} \\
\hline & & & & & & \\
\hline Lagged Centrality & $\begin{array}{c}0.650^{* * *} \\
(0.037)\end{array}$ & $\begin{array}{c}0.205^{\star * \star} \\
(0.035)\end{array}$ & $\begin{array}{c}0.678^{\star * *} \\
(0.035)\end{array}$ & $\begin{array}{c}0.255^{\star * *} \\
(0.032)\end{array}$ & $\begin{array}{c}0.597^{\star * *} \\
(0.036)\end{array}$ & $\begin{array}{c}0.428^{* * *} \\
(0.030)\end{array}$ \\
\hline $\begin{array}{l}\text { Productivity of existing } \\
\text { Buyers/Suppliers }\end{array}$ & $\begin{array}{l}0.151^{\star *} \\
(0.073)\end{array}$ & $\begin{array}{l}-0.006 \\
(0.056)\end{array}$ & $\begin{array}{c}0.055 \\
(0.076)\end{array}$ & $\begin{array}{l}-0.053 \\
(0.075)\end{array}$ & $\begin{array}{l}0.120 \\
(0.091)\end{array}$ & $\begin{array}{c}0.016 \\
(0.072)\end{array}$ \\
\hline
\end{tabular}

First Stage - Average Productivity (Centrality Weighted) of Buyers / Suppliers:

\begin{tabular}{|c|c|c|c|c|c|c|}
\hline $\begin{array}{l}\text { Productivity of existing } \\
\text { Buyers/Suppliers }\end{array}$ & $\begin{array}{c}0.965^{\star * *} \\
(0.012)\end{array}$ & $\begin{array}{c}0.991^{\star * *} \\
(0.040)\end{array}$ & $\begin{array}{l}1.037^{* * *} \\
(0.042)\end{array}$ & $\begin{array}{l}1.018^{* * *} \\
(0.041)\end{array}$ & $\begin{array}{l}0.790^{* * *} \\
(0.044)\end{array}$ & $\begin{array}{l}0.861^{* * *} \\
(0.049)\end{array}$ \\
\hline Lagged Centrality & $\begin{array}{c}-0.002 \\
(0.012)\end{array}$ & $\begin{array}{c}0.013 \\
(0.012)\end{array}$ & $\begin{array}{c}0.009 \\
(0.009)\end{array}$ & $\begin{array}{c}0.013 \\
(0.013)\end{array}$ & $\begin{array}{c}0.005 \\
(0.016)\end{array}$ & $\begin{array}{c}0.019 \\
(0.017)\end{array}$ \\
\hline
\end{tabular}

\begin{tabular}{lcccccc} 
Observations & $2,287,415$ & $2,287,415$ & $2,287,415$ & $2,287,415$ & $2,287,415$ & $2,287,415$ \\
YEAR FE & $\mathrm{Y}$ & $\mathrm{Y}$ & $\mathrm{Y}$ & $\mathrm{Y}$ & $\mathrm{Y}$ & $\mathrm{Y}$ \\
FIRM FE & $\mathrm{Y}$ & $\mathrm{Y}$ & $\mathrm{Y}$ & $\mathrm{Y}$ & $\mathrm{Y}$ \\
$\begin{array}{l}\text { FIRM SIZE } \\
\text { CONTROLS }\end{array}$ & $\mathrm{Y}$ & $\mathrm{Y}$ & $\mathrm{Y}$ & $\mathrm{Y}$ & $\mathrm{Y}$ & $\mathrm{Y}$ \\
$\begin{array}{l}\text { INDUSTRY } \\
\text { CONTROLS }\end{array}$ & $\mathrm{N}$ & $\mathrm{Y}$ & $\mathrm{N}$ & $\mathrm{Y}$ & $\mathrm{N}$ & $\mathrm{Y}$ \\
\hline
\end{tabular}

Robust standard errors clustered at country-(34 TiVA) industry level, ${ }^{\star \star \star} ~ p<0.01,{ }^{\star *} p<0.05,{ }^{*} p<0.1$

Firm size control reflects lagged employment. Industry controls include Domestic sources of centrality, Fally's (2011) GVC Upstreamness and GVC Length measures, Exports of intermediates, Imports of intermediates, Industry production (as a measure of industry size), Balassa's Gross Revealed Comparative Advantage, and Koopman et al.'s (2014) Value-Added Revealed Comparative Advantage. 


\section{OECD PRODUCTIVITY WORKING PAPERS}

OECD Productivity Working Papers are published on oe.cd/GFP

01. Institutions to promote pro-productivity policies: Logic and Lessons (November 2015) by Gary Banks

02. Frontier Firms, Technology Diffusion and Public Policy: Micro Evidence from OECD Countries

(November 2015) by Dan Andrews, Chiara Criscuolo and Peter N. Gal.

03. Policies for productivity growth

(March 2015) by Chang-Tai Hsieh

04. Could Mexico become the new "China" Policy drivers of competitiveness and productivity

(July 2016) by Sean M. Dougherty and Octavio R. Escobar

05. The Best versus the Rest: The Global Productivity Slowdown, Divergence across Firms and the Role of Public Policy

(November 2016) by Dan Andrews, Chiara Criscuolo and Peter N. Gal

06. What makes cities more productive? Agglomeration economies and the role of urban governance: Evidence from 5 OECD countries

(February 2017) by Rudiger Ahrend, Emily Farchy, Ioannis Kaplanis and Alexander C. Lembcke

07. Pro-Productivity Institutions: Learning From National Experience (April 2017) by Andrea Renda and Sean Dougherty

08. The impact of structural reforms on productivity: The role of the distance to the technological frontier

(May 2017) by Gustavo Monteiro, Ana Fountoura Gouveia and Sílvia Santos

09. Product markets' deregulation: A more productive, more efficient and more resilient economy?

(September 2017) by Gustavo Monteiro, Ana Fountoura Gouveia and Sílvia Santos

10. Achieving New Zealand's productivity potential (October 2017) by Paul Conway

11. The Contribution of Multinational Enterprises to Labor Productivity: The Case of Israel (February 2018) by Tatiana Slobodnitsky, Lev Drucker and Assaf Geva

12. GVCs and centrality: mapping key hubs, spokes and the periphery (February 2018) by Chiara Criscuolo and Jonathan Timmis

13. Fear the walking dead: zombie firms, spillovers and exit barriers (June 2018) by Ana Fontoura Gouveia and Christian Osterhold 